\title{
A global perspective on atmospheric blocking using GPS radio occultation - one decade of observations
}

\author{
Lukas Brunner ${ }^{1,2}$ and Andrea K. Steiner ${ }^{1,2,3}$ \\ ${ }^{1}$ Wegener Center for Climate and Global Change (WEGC), University of Graz, Graz, Austria \\ ${ }^{2}$ FWF-DK Climate Change, University of Graz, Graz, Austria \\ ${ }^{3}$ Institute for Geophysics, Astrophysics, and Meteorology, Institute of Physics, University of Graz, Graz, Austria \\ Correspondence to: Lukas Brunner (lukas.brunner@uni-graz.at)
}

Received: 20 June 2017 - Discussion started: 5 July 2017

Revised: 16 November 2017 - Accepted: 20 November 2017 - Published: 5 December 2017

\begin{abstract}
Atmospheric blocking represents a weather pattern where a stationary high-pressure system weakens or reverses the climatological westerly flow at mid-latitudes for up to several weeks. It is closely connected to strong anomalies in key atmospheric variables such as geopotential height, temperature, and humidity. Here we provide, for the first time, a comprehensive, global perspective on atmospheric blocking and related impacts by using an observation-based data set from Global Positioning System (GPS) radio occultation (RO) from 2006 to 2016. The main blocking regions in both hemispheres and seasonal variations are found to be represented well in RO data. The effect of blocking on vertically resolved temperature and humidity anomalies in the troposphere and lower stratosphere is investigated for blocking regions in the Northern and Southern hemispheres, respectively. We find a statistically significant correlation of blocking with positive temperature anomalies, exceeding $3 \mathrm{~K}$ in the troposphere, and a reversal above the tropopause with negative temperature anomalies below $-3 \mathrm{~K}$ in the lower stratosphere. Specific humidity is positively correlated with temperature throughout the troposphere with larger anomalies revealed in the Southern Hemisphere. At the eastern and equatorward side of the investigated blocking regions, a band of tropospheric cold anomalies reveals advection of cold air by anticyclonic motion around blocking highs, which is less distinct in the Southern Hemisphere due to stronger zonal flow. We find GPS RO to be a promising new data set for blocking research that gives insight into the vertical atmospheric structure, especially in light of the expected increase in data coverage that future missions will provide.
\end{abstract}

\section{Introduction}

Global weather and climate are determined by different processes such as the jet stream, the storm tracks, and blocking. Blocking is a particularly important feature in many regions at mid-latitudes (e.g. Woollings, 2010). It describes a synoptic situation, in which a strong and stationary high-pressure system weakens or reverses the climatological eastward flow at mid-latitudes (Rex, 1950; Trenberth and Mo, 1985; Tibaldi and Molteni, 1990; Pelly and Hoskins, 2003; Barriopedro et al., 2006; Croci-Maspoli et al., 2007; Oliveira et al., 2014). Due to its persistence of up to several weeks, atmospheric blocking significantly influences key atmospheric variables such as geopotential height (GPH), temperature, and humidity throughout the troposphere and lower stratosphere. Further impacts of blocking are surface extremes which can lead to severe damages on economy and society (e.g. GarcíaHerrera et al., 2010; Gilbert, 2010; Rodrigues and Woollings, 2017).

In the Northern Hemisphere (NH), the main blocking regions are located over the North Atlantic and Europe (EuroAtlantic blocking region) as well as over the North Pacific (also referred to as the Alaskan blocking region) (Barriopedro et al., 2010; Whan et al., 2016). The impact of blocking on surface temperature extremes is well established for both regions and different seasons (e.g. Favre and Gershunov, 2006; Buehler et al., 2011; Pfahl and Wernli, 2012; Bieli et al., 2015; Whan et al., 2016; Brunner et al., 2017). The connection to humidity, precipitation, and droughts has also been intensively investigated, especially in recent years (e.g. Carrera et al., 2004; Galarneau et al., 2012; Pfahl et al., 2015; Wise, 2016; Sousa et al., 2017). 
In the Southern Hemisphere (SH), blocking occurs in the entire South Pacific between $160^{\circ} \mathrm{E}$ and $75^{\circ} \mathrm{W}$. The highest frequencies are found in the south-eastern Pacific during winter (e.g. de Adana and Colucci, 2005; Berrisford et al., 2007; Parsons et al., 2016). However, in the SH blocking occurrence is considerably lower than in the NH. Furthermore, the impacts of blocking on populated areas are weaker compared to the NH (e.g. Lejenäs, 1984; de Adana and Colucci, 2005). Due to this imbalance comparably few studies investigate blocking in the SH, mostly focusing on impacts in Australia and New Zealand (Australian-New Zealand blocking region) and in South America (south-eastern Pacific blocking region) (e.g. Marques and Rao, 1999; Cowan et al., 2013; Pook et al., 2013; Parker et al., 2014). Several studies have also looked into the influence of other phenomena like the El Niño-Southern Oscillation (ENSO) or the Antarctic oscillation (also known as Southern Annular Mode) on SH blocking (Damião Mendes and Cavalcanti, 2014; Oliveira et al., 2014).

The systematic and global detection and analysis of atmospheric blocking as well as its impacts set demanding requirements of the data sets in use. Apart from global coverage, observations with high spatial and temporal resolution are needed. Hence, blocking research mainly relies on model output and reanalysis data rather than using direct observations. However, most models show only limited skill in blocking representation, as has been noted by many studies in the past (D'Andrea et al., 1998; Vial and Osborn, 2012; Barnes et al., 2012; Anstey et al., 2013; Christensen et al., 2013; Dunn-Sigouin and Son, 2013; Masato et al., 2013). Recently, Davini and D'Andrea (2016) showed that current climate models still underrepresent blocking occurrence by up to $50 \%$, particularly in the Euro-Atlantic blocking region. Reanalyses combine an atmospheric model with a range of observations from different measurement systems to approximate the atmospheric state as accurately as possible. Due to this data assimilation the accuracy of reanalyses is less well understood compared to observations (Parker, 2016). In addition, there can be significant differences between different reanalyses and the causes are not yet fully understood (Fujiwara et al., 2017). Brunner et al. (2016) demonstrated the potential of Global Positioning System (GPS) radio occultation (RO) to detect and analyse blocking in this observational data set, using two exemplary blocking cases in 2010 and 2013. GPS RO provides highly accurate measurements of atmospheric variables and has therefore the potential to complement models and reanalyses as data set for blocking research.

In this study we provide, for the first time, a global perspective on atmospheric blocking based on the RO record from September 2006 to August 2016 exploiting its good vertical resolution for investigating the atmospheric vertical structure in temperature and humidity during blocking events. In Sect. 2, we introduce the RO record as well as the reanalysis data sets used for comparison. Section 3 describes the blocking detection algorithm, the gridding method for
$\mathrm{RO}$, and the computation of anomalies, composites, and significance testing. We present the results of our study in Sect. 4 and conclude with a summary in Sect. 5 .

\section{Data}

\subsection{Radio occultation data}

GPS RO is an active limb-sounding technique (Kursinski et al., 1997; Hajj et al., 2002). The measurements are characterised by global coverage, high vertical resolution, high accuracy, and no need for inter-satellite calibration (e.g. Foelsche et al., 2011; Ho et al., 2012; Steiner et al., 2013). The resolution reaches about $60 \mathrm{~km}$ horizontally and $100 \mathrm{~m}$ vertically in the lower troposphere and about $300 \mathrm{~km}$ horizontally and $1.5 \mathrm{~km}$ vertically in the lower stratosphere (Melbourne et al., 1994; Kursinski et al., 1997; Gorbunov et al., 2004). RO data have, so far, been used for a range of different applications in monitoring atmospheric variability and changes in Earth's climate (Anthes, 2011; Steiner et al., 2011; Gleisner et al., 2015; Randel and Wu, 2015). Significant improvement of weather forecasting (e.g. Healy and Thépaut, 2006; Cardinali, 2009) and atmospheric reanalyses (e.g. Poli et al., 2010; Simmons et al., 2014) has been made since RO observations can be assimilated without bias correction and act as anchor measurements. Including RO into reanalyses can reduce biases in the troposphere and stratosphere in both hemispheres (Poli et al., 2010). Several studies also used RO data to investigate dynamical features of the atmosphere such as waves (Randel and $\mathrm{Wu}, 2005$; de la Torre and Alexander, 2005; Tsuda, 2014), the ENSO (ScherllinPirscher et al., 2012; Sun et al., 2014), tropopause characteristics (Schmidt et al., 2008; Rieckh et al., 2014; Peevey et al., 2014; Randel et al., 2003; Schmidt et al., 2005), and blocking (Brunner et al., 2016).

In this study we use RO data processed by the Wegener Center occultation processing system version 5.6 (OPSv5.6). Quality-controlled measurements (Angerer et al., 2017) for the 10-year period from September 2006 to August 2016 are selected, including data from CHAMP, FORMOSAT3/COSMIC, C/NOFS, GRACE, SAC-C, and TerraSAR-X. A detailed description of the OPS retrieval is given by Schwärz et al. (2016, Appendix A therein). Error estimates are provided by Scherllin-Pirscher et al. (2017). The accuracy of the data is best in the upper troposphere and lower stratosphere with $0.7 \mathrm{~K}$ in temperature and $10 \mathrm{~m}$ in GPH for individual profiles (Scherllin-Pirscher et al., 2011b, 2017) and even better when averaging over a range of profiles (ScherllinPirscher et al., 2011a).

We compute daily fields at a regular $2.5^{\circ} \times 2.5^{\circ}$ grid using a weighted average in space and time applied to the randomly distributed RO events, following 
Table 1. Summary of reanalysis products, their resolution, assimilation of GPS RO data, and reference publications.

\begin{tabular}{lllll}
\hline Name & Provider & Downloaded resolution & RO assimilation & Reference \\
\hline ERA-Interim & ECMWF & $6 \mathrm{~h}, 2.5^{\circ} \times 2.5^{\circ}$ & Since 1 January 2001 & Poli et al. (2010), Dee et al. (2011) \\
JRA-55 & JMA & $6 \mathrm{~h}, 1.25^{\circ} \times 1.25^{\circ}$ & Since 1 January 2001 & Ebita et al. (2011), Kobayashi et al. (2015) \\
MERRA-2 & NASA & $6 \mathrm{~h}, 0.625^{\circ} \times 0.5^{\circ}$ & Since 15 July 2004 & McCarty et al. (2016), Gelaro et al. (2017) \\
\hline
\end{tabular}

$x_{\text {grid }}(\lambda, \phi, d)=\frac{\sum_{i} w_{i} x_{i}\left(\lambda^{\prime}, \phi^{\prime}, d^{\prime}\right)}{\sum_{i} w_{i}}$,

where $x_{\text {grid }}(\lambda, \phi, d)$ represents a certain grid cell centred at longitude $\lambda$, latitude $\phi$, and day $d$. Each RO event $x_{i}\left(\lambda^{\prime}, \phi^{\prime}, d^{\prime}\right)$ within $\pm 7.5^{\circ}$ in longitude, $\pm 2.5^{\circ}$ in latitude, and \pm 2 days of the grid cell centre is considered and weighted with a Gaussian weighting function, $w_{i}$. The weighting function is given as

$w_{i}=\exp \left(-\left[\left(\frac{\Delta \lambda}{L}\right)^{2}+\left(\frac{\Delta d}{D}\right)^{2}\right]\right)$,

with $\Delta \lambda=\lambda-\lambda^{\prime}, \Delta d=d-d^{\prime}, L=7.5^{\circ}$, and $D=1$ day. This effective resolution has been chosen to minimise the number of empty grid cells while maintaining most of the atmospheric variability. For more detailed information on the applied gridding method we refer to Brunner et al. (2016).

\subsection{Reanalysis data}

Different reanalyses have extensively been used to investigate blocking and to evaluate the model performance in blocking representation (e.g. Sinclair, 1996; Trigo et al., 2004; Sillmann et al., 2011; IPCC, 2013; Davini and D'Andrea, 2016; Schiemann et al., 2017). Here, we selected three of the more recent reanalyses (Table 1), which compare well against each other, e.g. in terms of temperature and zonal winds (e.g. Long et al., 2017), to investigate their representation of blocking in comparison to $\mathrm{RO}$ : the European Centre for Medium-Range Weather Forecasts (ECMWF) Reanalysis Interim (ERA-Interim), the Japanese 55-year Reanalysis (JRA-55) by the Japan Meteorological Agency (JMA), and the recently published second ModernEra Retrospective analysis for Research and Applications (MERRA-2) by the National Aeronautics and Space Administration (NASA). We use GPH at the $500 \mathrm{hPa}$ pressure level from September 2006 to August 2016, from ERA-Interim, JRA-55, and MERRA-2 for blocking detection. All three reanalyses have a native 6-hourly time resolution, which is averaged to daily fields. The varying spatial resolutions are interpolated to a consistent $2.5^{\circ} \times 2.5^{\circ}$ longitude-latitude grid.

All three reanalyses assimilate RO data. ERA-Interim includes measurements from CHAMP, FORMOSAT3/COSMIC, GRACE, MetOp, and TerraSAR-X (Poli et al.,
2010; Dee et al., 2016); MERRA-2 additionally includes SAC-C (McCarty et al., 2016); and JRA-55 all the former plus C/NOFS (Kobayashi et al., 2015).

\section{Methods}

A blocking detection algorithm based on the reversal of $500 \mathrm{hPa}$ GPH gradients is applied to the RO data between September 2006 and August 2016. Resulting blocking frequencies are investigated with regard to their horizontal and temporal evolution and compared to established reanalyses. Three main blocking regions in both hemispheres are selected and the vertical atmospheric structure of temperature and specific humidity anomalies during blocking in these regions is analysed. Statistically significant links between blocking and the anomalies in temperature and specific humidity are found via a Monte Carlo test.

\subsection{Blocking detection in RO GPH fields}

We use a standard $500 \mathrm{hPa}$ GPH gradient algorithm (Tibaldi and Molteni, 1990; Scherrer et al., 2006; Davini et al., 2012, 2014), adapted to allow the simultaneous detection of blocking in the $\mathrm{NH}$ and SH. First, GPH gradients to the north $\left(\Delta Z_{\mathrm{N}}\right)$ and to the south $\left(\Delta Z_{\mathrm{S}}\right)$ are calculated for each grid cell:

$$
\begin{aligned}
& \Delta Z_{\mathrm{N}}(\lambda, \phi)=\frac{Z(\lambda, \phi+\Delta \phi)-Z(\lambda, \phi)}{\Delta \phi}, \\
& \Delta Z_{\mathrm{S}}(\lambda, \phi)=\frac{Z(\lambda, \phi-\Delta \phi)-Z(\lambda, \phi)}{\Delta \phi},
\end{aligned}
$$

with the longitude $\lambda$ running from $180^{\circ} \mathrm{W}$ to $177.5^{\circ} \mathrm{E}$ and the latitude $\phi$ running from $72.5^{\circ} \mathrm{S}$ to $72.5^{\circ} \mathrm{N}$. The gradient is calculated over a latitude width of $\Delta \phi=15^{\circ}$. By this definition the northern gradient $\Delta Z_{\mathrm{N}}$ is positive if the GPH is higher to the north and equivalently $\Delta Z_{\mathrm{S}}$ is positive if the $\mathrm{GPH}$ is higher to the south.

GPH-based blocking detection indices are usually restricted in latitude to avoid the detection of low-latitude atmospheric waves which are not considered as blocking in the classical sense (e.g. Scherrer et al., 2006; Barriopedro et al., 2006; Martineau et al., 2017). Particularly in hemispheric summer, the poleward shift of slow-moving atmospheric ridges can otherwise lead to very high blocking frequencies equatorward of $45^{\circ}$ latitude (e.g. Davini et al., 
2014). In order to avoid the detection of low-latitude blocking and to ensure comparability of our results with existing literature, we introduce a third gradient towards the Equator $\left(\Delta Z_{\mathrm{E}}\right)$, following Davini et al. (2012):

$$
\begin{aligned}
& \Delta Z_{\mathrm{E}}(\lambda, \phi)=\frac{Z(\lambda, \phi \mp 2 \times \Delta \phi)-Z(\lambda, \phi \mp \Delta \phi)}{\Delta \phi} \\
& \text { with }\left\{\begin{array}{l}
- \text { in the } \mathrm{NH} \\
+ \text { in the SH, }
\end{array}\right.
\end{aligned}
$$

where the minus sign is valid in the $\mathrm{NH}$ and the plus sign is valid in the $\mathrm{SH}$. To put it simply, $\Delta Z_{\mathrm{E}}$ is defined positive at a certain grid cell if there is a clear trough in the GPH field towards the Equator and is used to prohibit the identification of slow-moving low-latitude ridges as blocking.

Instantaneous blocking (IB) is identified on a grid cell basis when the following three conditions are simultaneously met:

$$
\begin{aligned}
& \Delta Z_{\mathrm{N}}(\lambda, \phi)\left\{\begin{array}{l}
<-10 \mathrm{~m}\left({ }^{\circ} \text { lat. }\right)^{-1} \text { in the } \mathrm{NH} \\
<0 \mathrm{~m}\left({ }^{\circ} \text { lat. }\right)^{-1} \text { in the } \mathrm{SH},
\end{array}\right. \\
& \Delta Z_{\mathrm{S}}(\lambda, \phi)\left\{\begin{array}{l}
<0 \mathrm{~m}\left({ }^{\circ} \text { lat. }\right)^{-1} \text { in the } \mathrm{NH} \\
<-10 \mathrm{~m}\left({ }^{\circ} \text { lat. }\right)^{-1} \text { in the } \mathrm{SH},
\end{array}\right. \\
& \Delta Z_{\mathrm{E}}(\lambda, \phi)>5 \mathrm{~m}\left({ }^{\circ} \text { lat. }\right)^{-1} \text { for both hemispheres. }
\end{aligned}
$$

We only consider IB events with an extent of at least $15^{\circ}$ in longitude and filter out smaller blocking systems. In a final step, we define blocking for a given day and grid cell when such a large-scale event is also persistent and stationary, requesting IB to be found within a $10^{\circ} \times 5^{\circ}$ longitudelatitude region in the neighbouring \pm 2 days. Reducing the longitude-latitude view, one-dimensional blocking frequencies consider a given longitude in the $\mathrm{NH}$ or $\mathrm{SH}$ as blocked if at least one latitude is blocked.

To investigate the effects of blocking on temperature and humidity we further define blocked days with respect to three selected regions. A blocked day is found if at least one grid point is blocked in such a region. The regions are chosen to cover the blocking maxima in both hemispheres. These main blocking regions are, in the following, referred to as the North Atlantic region $\left(30^{\circ} \mathrm{W}\right.$ to $10^{\circ} \mathrm{E}$ and 30 to $\left.72.5^{\circ} \mathrm{N}\right)$, the North Pacific region $\left(160^{\circ} \mathrm{E}\right.$ to $160^{\circ} \mathrm{W}$ and 30 to $\left.72.5^{\circ} \mathrm{N}\right)$, and the East Pacific region ( 150 to $90^{\circ} \mathrm{W}$ and 72.5 to $30^{\circ} \mathrm{S}$ ). The coincidence of temperature and humidity anomalies during blocked days is tested statistically (see Sect. 3.3) in order to investigate the effects of blocking on the atmospheric temperature and humidity structure (see Sect. 4.2).

\subsection{Anomaly computation in RO temperature and humidity fields}

Anomalies of atmospheric temperature $\left(T_{\text {Anom }}\right)$ and relative specific humidity $\left(q_{\text {Anom }}\right)$ during blocked days $t$ are calcu- lated for each location $(\lambda, \phi)$ and pressure level $p$ :

$T_{\text {Anom }}=T-\bar{T}$,

$q_{\mathrm{Anom}}=\frac{q-\bar{q}}{\bar{q}} \times 100 \%$,

with temperature $T=T(t, \lambda, \phi, p)$ and specific humidity $q=q(t, \lambda, \phi, p)$. Respective daily mean values $\bar{T}=$ $\bar{T}(d, \lambda, \phi, p)$ and $\bar{q}=\bar{q}(d, \lambda, \phi, p)$ are calculated over the 10 years from September 2006 to August 2016 for each day of the year $d$. For specific humidity we show relative anomalies to allow easier comparison across different pressure levels due to its exponential decline with altitude. Composites of the temperature and specific humidity anomalies are then obtained by averaging over all blocked days $t$ of a certain region.

\subsection{Statistical significance testing}

Statistical significance of the composites is determined for each pressure level on a grid cell basis using a Monte Carlo test. Given $n$ blocked days in a certain region and period, 1000 samples of $n$ random days are drawn from the same period (e.g. season) and averaged. To conserve the autocorrelation, consecutive blocked days are clustered and lead to consecutive days in the random samples. Based on the 1000 random samples the probability density function (PDF) is calculated, with values below the 5 th or above the 95 th percentile of this PDF being considered statistically significant.

\section{Results}

\subsection{Blocking climatologies from RO}

Figure 1 shows annual mean blocking frequencies derived from the RO data set and the three reanalyses, ERA-Interim, JRA-55, and MERRA-2. All four data sets agree on the two main blocking regions in the NH (Fig. 1a). There is a clear maximum in the blocking frequency in the EuroAtlantic blocking region between $50^{\circ} \mathrm{W}$ and $50^{\circ} \mathrm{E}$ and a smaller maximum in the North Pacific blocking region between $150^{\circ} \mathrm{E}$ and $150^{\circ} \mathrm{W}$ (compare IPCC, 2013, Box 14.2). In the Euro-Atlantic region, the maximum frequency is between about $10 \%$ for ERA-Interim and JRA-55 and about $10.5 \%$ for MERRA-2, while the maximum RO frequency is a bit lower with $8 \%$. In addition, the RO maximum in this region is shifted by about $10^{\circ}$ to the east compared to the reanalyses. All four data sets consistently place the minimum blocking frequency east of the Euro-Atlantic region at $100^{\circ} \mathrm{E}$. RO shows frequencies of $2 \%$ here, ERA-Interim and JRA-55 are about $1 \%$ higher, and MERRA-2 is about $1.5 \%$ higher. In the North Pacific region, RO reaches a maximum frequency of about $6 \%$, while the reanalyses show about 7 to $8 \%$. The region with lowest blocking frequencies below $1 \%$ is found at $90^{\circ} \mathrm{W}$ across all data sets. In general, $\mathrm{RO}$ 

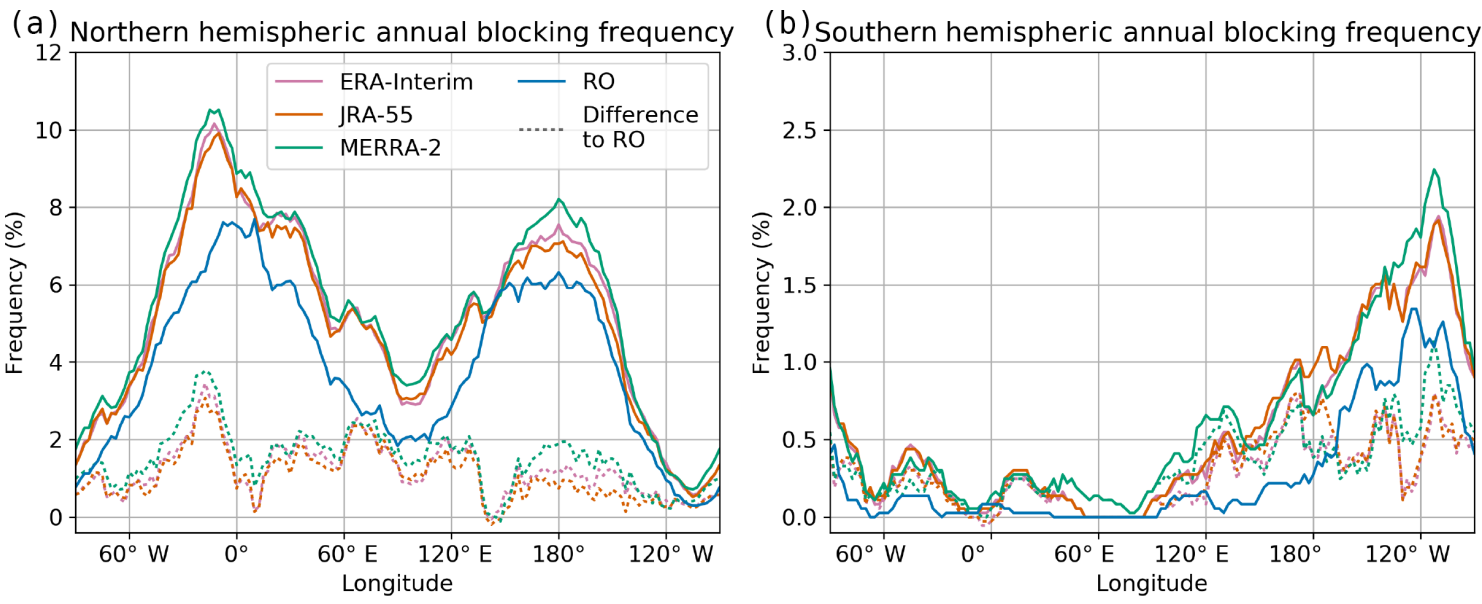

Figure 1. Annual mean blocking frequencies for the (a) Northern and (b) Southern Hemisphere in the period September 2006 to August 2016. Each coloured line represents a data set, the dashed lines show the respective differences of reanalyses to RO. Note the different $y$-axis ranges.

data show an underestimation of one-dimensional blocking frequencies. The absolute difference to the reanalyses stays below $2 \%$ at most longitudes. Only near the maximum in the Euro-Atlantic blocking region the difference exceeds $3 \%$.

Figure $1 \mathrm{~b}$ shows the $\mathrm{SH}$ blocking distribution. Again, all data sets agree on the main blocking region in the South Pacific, with RO again showing a slight underestimation of about $0.5 \%$. Highest frequencies are consistently found in the south-eastern Pacific between 150 and $100^{\circ}$ W. MERRA2 shows the highest maximum frequency with about $2.25 \%$, followed by ERA-Interim and JRA-55 with about $2 \%$, and RO with about $1.25 \%$. Eastward of the south-eastern Pacific region, RO shows hardly any blocking and all three reanalyses stay below $0.5 \%$ blocking frequency as well (corresponding to about 2 blocked days per year on average). In the Australian-New Zealand region between $100^{\circ} \mathrm{E}$ and $150^{\circ} \mathrm{W}$, RO blocking frequencies hardly exceed $0.5 \%$ and the reanalyses hardly exceed $1 \%$.

The time evolution of blocking is presented in Fig. 2 for both hemispheres from September 2006 to August 2016. Both main blocking areas in the $\mathrm{NH}$, as well as the South Pacific region in the $\mathrm{SH}$ are clearly recognisable in this view. A closer inspection reveals that a $\mathrm{NH}$ blocking has an average duration of 4 days and an average longitudinal extent of about $34^{\circ}$. The most persistent and continuous blocking cases in the NH occurred in March-April 2007 (27 days), in December-January 2009/2010 (28 days), and in February 2015 (23 days). All three cases were connected to unusual temperature anomalies, as e.g. discussed by Cattiaux et al. (2010) for winter 2009/2010 with severe cold spells hitting Europe.

Note that blocking can show considerable fluctuations in intensity during its evolution so that blocking cases may be interrupted by a few unblocked days and are not regarded as continuous signal. An example is the sequence of blockings in summer 2010 (see e.g. Brunner et al., 2016, Fig. 3) leading to a severe heat wave in Russia (e.g. Barriopedro et al., 2011).

In the $\mathrm{SH}$, an average blocking only lasts 2.5 days and has an extent of $23^{\circ}$ in longitude. There, the most persistent blocking cases are found in May-June 2012 (12 days), in July-August 2014 (8 days), and in September 2015 (8 days). In general, blocking in the SH is by far weaker and less frequent than in the $\mathrm{NH}$.

Taking a closer look into the characteristic blocking features, we further investigate the distribution of blocking frequencies in longitude and latitude for different seasons. Figure 3 shows horizontally resolved blocking frequencies for all seasons in the NH for RO and ERA-Interim. A comparison of blocking frequencies with JRA-55 and MERRA-2 is not shown as they are highly consistent and agree within $0.2 \%$ annual mean blocking frequency to ERA-Interim. RO resolves all the main features in the $\mathrm{NH}$ blocking distribution. Annual mean frequencies from RO show the main blocking regions over the North Atlantic and Europe (EuroAtlantic blocking region) as well as a maximum over the North Pacific. In the seasonally resolved analysis, RO detects the highest blocking frequencies over the Euro-Atlantic region during winter (DJF) and spring (MAM) consistent with ERA-Interim. Blocking occurrence in the North Pacific region is high during the entire year, with fewest blockings in fall (SON). In general, RO and ERA-Interim agree very well on the location of the blocking regions in all seasons. Larger differences exceeding $2 \%$ are only found in $\mathrm{NH}$ summer (JJA), where RO does not fully capture the frequency maxima over northern Russia. In winter, RO shows slightly higher blocking frequencies than ERA-Interim in the North Atlantic and over Scandinavia.

One possible reason for the generally lower blocking frequencies in the RO record is the measurement density of the RO events. As described in Sect. 2, RO data are aver- 
(a) Hovmöller diagram Northern Hemisphere

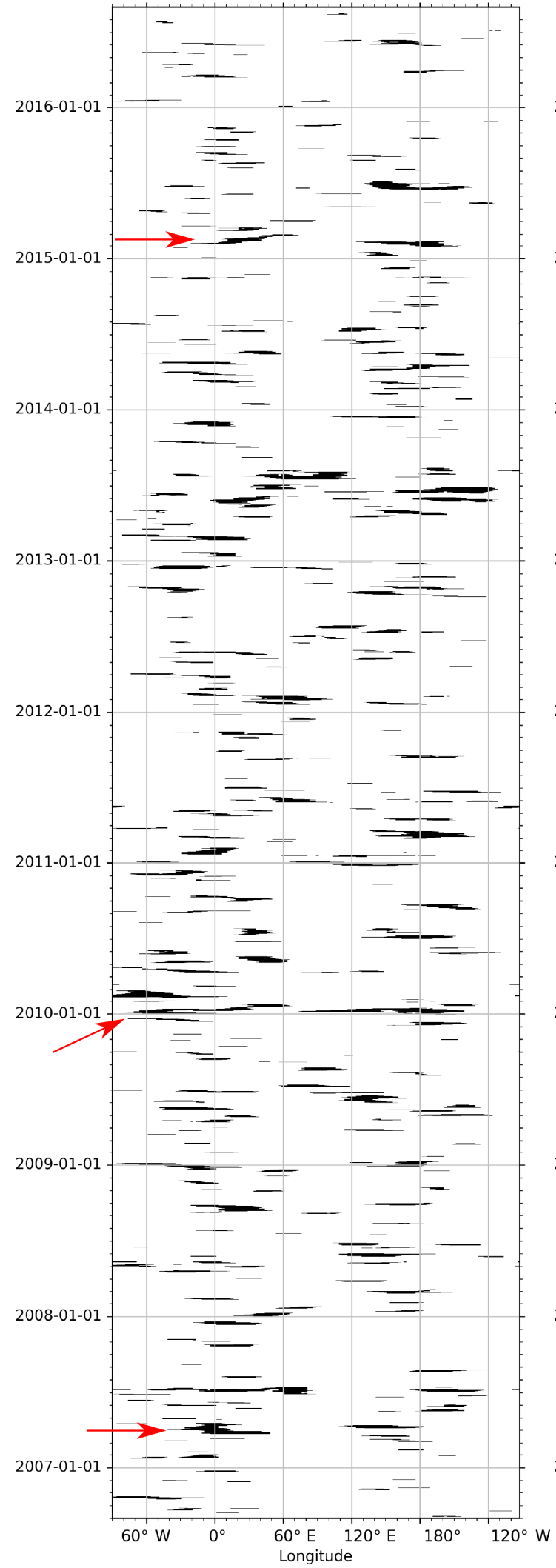

(b) Hovmöller diagram Southern Hemisphere

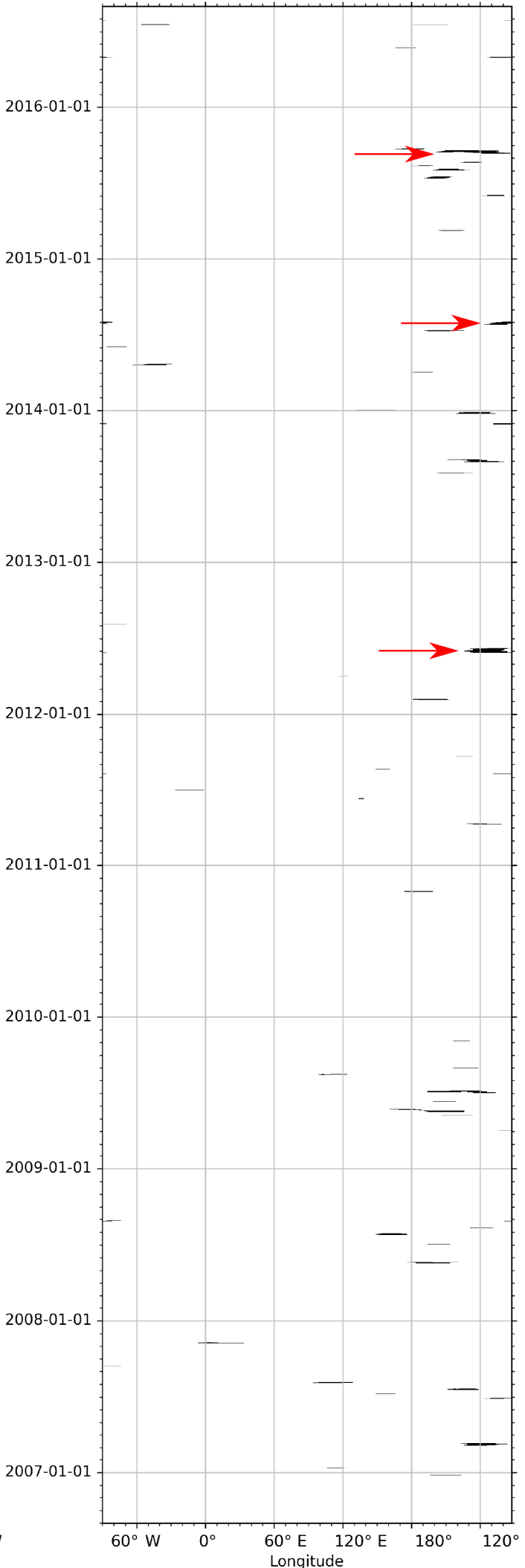

Figure 2. Hovmöller diagram of blocking as function of time over longitudes for the (a) Northern and (b) Southern Hemisphere based on the RO record for the period September 2006 to August 2016. Red arrows mark the three longest blocking events in each hemisphere. 
(a)

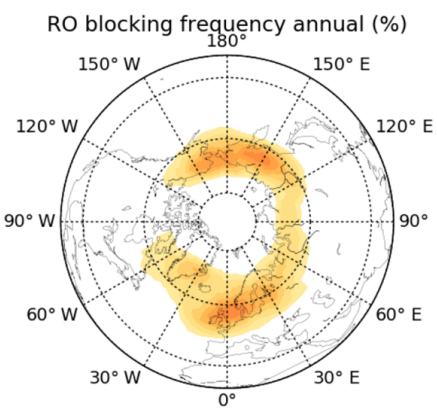

RO blocking frequency MAM (\%)

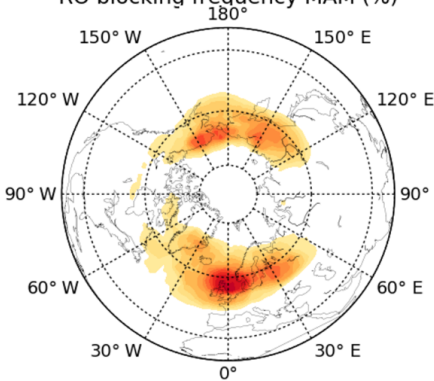

RO blockinq frequency JJA (\%)

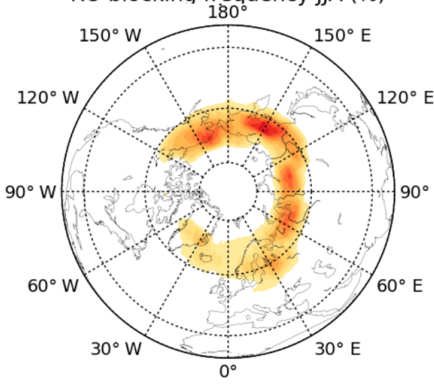

RO blockina freauency SON (\%)
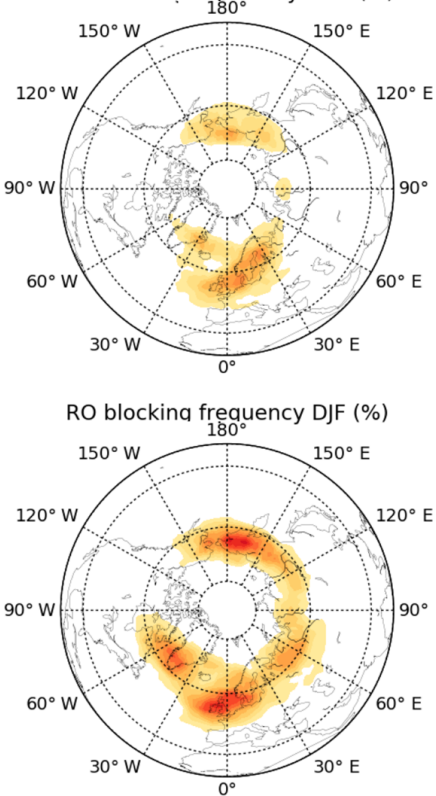

(b)

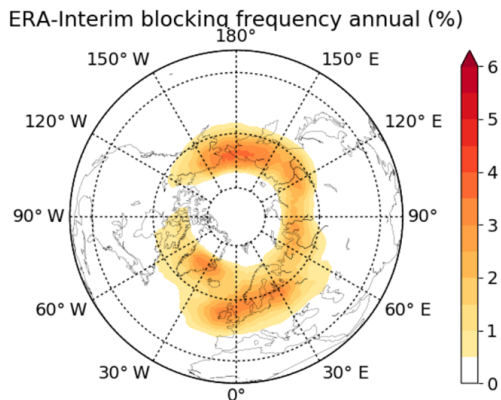

ERA-Interim blocking frequency MAM (\%)

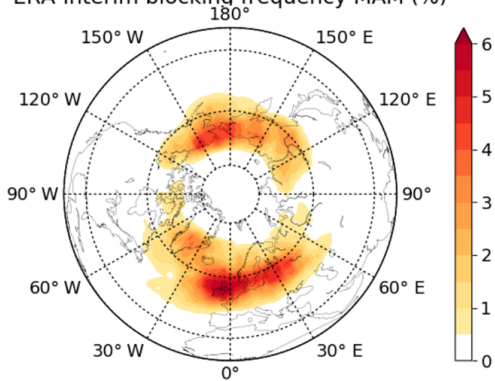

ERA-Interim blocking frequency JJA (\%)

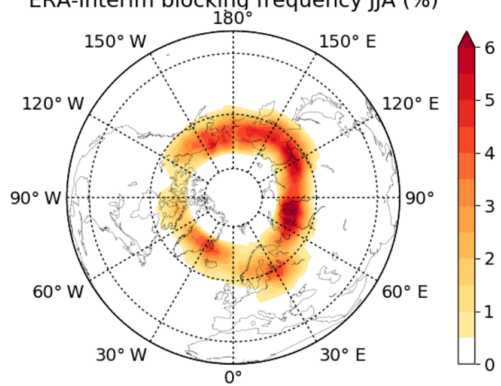

ERA-Interim blocking frequency SON (\%)

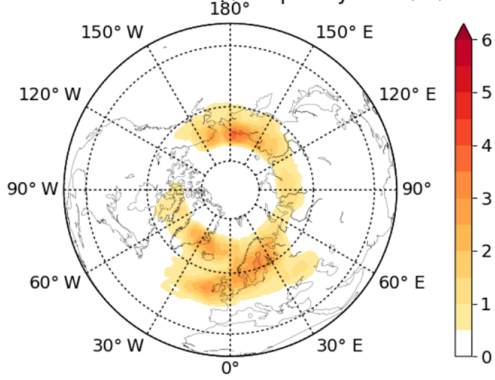

ERA-Interim blockina frequency DJF (\%)

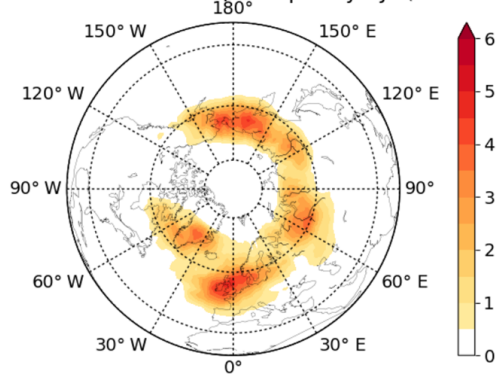

(c)

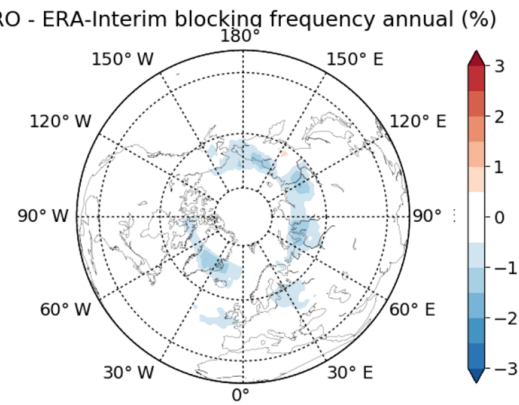

RO - ERA-Interim blockina frequency MAM (\%)

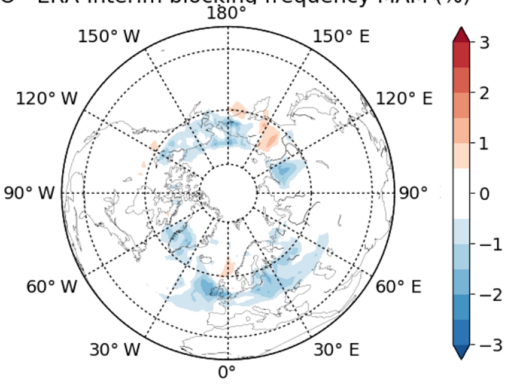

RO - ERA-Interim blocking frequency JJA (\%)

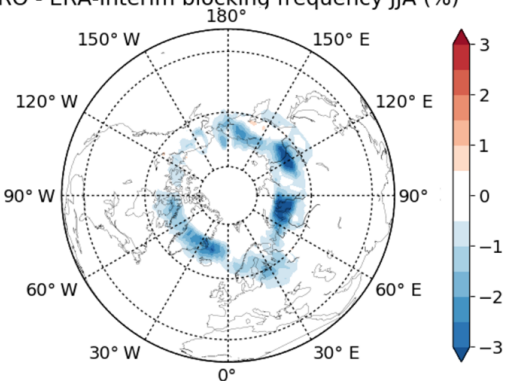

RO - ERA-Interim blockina frequency SON (\%)

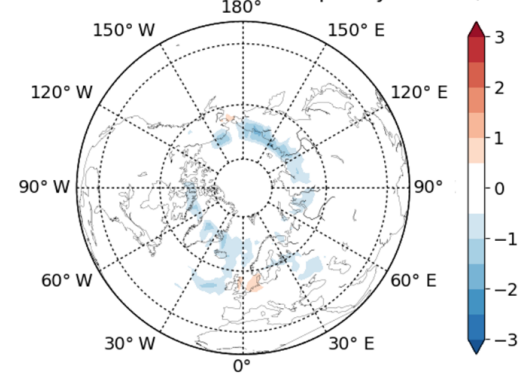

RO - ERA-Interim blockina frequency DJF (\%)

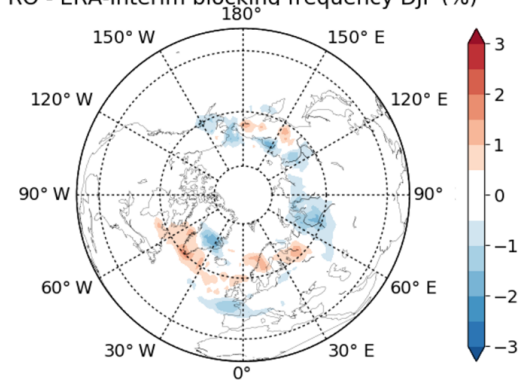

Figure 3. Blocking frequencies for the Northern Hemisphere in the period September 2006 to August 2016. Frequencies are shown for (a) RO, (b) ERA-Interim, and (c) RO minus ERA-Interim for (from top to bottom) the annual mean and seasonal means, spring, summer, fall, and winter. 
aged from the randomly distributed measurements to a regular daily grid using a weighted mean. Due to the random distribution of observations, some grid cells may not have any contributing RO events (see also Brunner et al., 2016, for a detailed analysis). Such empty grid cells can artificially lower the blocking frequency if they appear at the location of a blocking.

We tested the effect of the weighted averaging in the gridding of RO data and applied the same weighted averaging in space and time to ERA-Interim data. Comparing then blocking frequencies from the similarly weighted ERA-Interim fields to RO yields slightly reduced differences in blocking frequency and shows that about $0.5 \%$ in difference can be explained by the weighted averaging.

In the $\mathrm{SH}$, the overall blocking frequency is notably lower compared to the NH. It has been argued that the stronger zonal flow at mid-latitudes in the SH leads to less persistent blocking conditions (e.g. Trenberth and Mo, 1985). Oliveira et al. (2014) suggest a 3-day stationarity criterion for blocking detection in the $\mathrm{SH}$ as opposed to the typical 5-day criterion in the $\mathrm{NH}$ to account for the stronger westerlies. However, we here aim at a consistent comparison of blocking in both hemispheres and therefore use the 5-day criterion globally. This approach allows a direct comparison of blocking anticyclones and their impacts in both hemispheres.

In the $\mathrm{SH}$, blocking is almost exclusively found in the South Pacific (Fig. 4). Normally two sub-regions are distinguished mainly with regard to the impact on populated areas: blocking in the south-western Pacific (often referred to as the Australian-New Zealand blocking region) and blocking in the south-eastern Pacific region (influencing populated areas in South America; referenced to as the East Pacific region). In contrast to the $\mathrm{NH}, \mathrm{SH}$ blocking is mainly constraint to the southern winter (JJA) season, where two-dimensional frequencies can reach $2 \%$. RO and ERA-Interim consistently show this seasonal development. Differences between the two data sets stay mostly below $0.25 \%$ annually and below $0.5 \%$ seasonally. Largest differences are found during the blocking maximum in $\mathrm{SH}$ winter.

\subsection{Atmospheric temperature and specific humidity response to blocking}

In the following we investigate the atmospheric structure of vertically resolved temperature and relative specific humidity anomalies in the troposphere and lower stratosphere during blocked days. The effects of blocking are shown for three regions (two in the $\mathrm{NH}$, one in the $\mathrm{SH}$ ) and for five selected pressure levels: 850, 500, 270, 200, and $100 \mathrm{hPa}$. These levels represent (bottom to top) regions of main blocking influence in the lower- and middle-tropospheric region, the tropopause region, the region of main blocking influence in the lowest stratosphere and of decreasing influence in the stratosphere above.
Winter and summer seasons are compared in Figs. 5 and 6 for temperature and relative specific humidity anomalies during blocked days over the North Atlantic region showing extended winter (NDJFM) and extended summer (MJJAS), respectively. During winter a clear and statistically significant positive temperature anomaly dominates most of the blocking region throughout the troposphere up to about $300 \mathrm{hPa}$ (Fig. 5a). The anomalies reach about $2 \mathrm{~K}$ in the lower troposphere and exceed $3 \mathrm{~K}$ at their maximum at about $500 \mathrm{hPa}$. At upper levels, the positive anomalies decrease towards the tropopause. Beginning near $300 \mathrm{hPa}$, the decrease is accompanied by a shift to the north. The temperature anomalies are smallest at about $270 \mathrm{hPa}$, where they change from positive to negative. In the lower stratosphere, increasingly negative temperature anomalies, falling below $-3 \mathrm{~K}$ at $200 \mathrm{hPa}$, are the dominating feature. At higher altitudes, the influence of blocking on the temperature weakens and the anomalies decrease. A noticeable feature is also that the temperature anomalies are not centred in the blocking region in the troposphere near $500 \mathrm{hPa}$ but appear to be shifted to the west. This asymmetry disappears at higher altitudes and especially the lower-stratospheric cold anomalies are perfectly centred in the blocking region.

In the troposphere the central positive temperature anomaly is surrounded by a cold anomaly on the northern, eastern, and southern flanks. This anomaly, which is considerably weaker in summer (see Fig. 6), hints at the influence of the circulation during blocked conditions. The anticyclonic motion of air around stationary high-pressure systems in the investigated region favours the advection of cold air from the north towards central Europe. The cold anomalies are stronger in the lower regions of the troposphere, falling below $-2 \mathrm{~K}$ at $850 \mathrm{hPa}$. At $500 \mathrm{hPa}$ a band of cold air with composite temperatures below $-1 \mathrm{~K}$ is still visible to the east and south of the positive anomaly which change above the tropopause at the 200 and $100 \mathrm{hPa}$ level into positive anomalies of about 0.5 to $1.5 \mathrm{~K}$, especially north and south of the central cold anomaly.

The analysis of relative specific humidity anomaly composites (Fig. 5b) reveals a clear correlation with temperature in most of the troposphere: positive temperature anomalies are accompanied by positive specific humidity anomalies and negative temperature anomalies are accompanied by negative specific humidity anomalies. However, dry anomalies are mostly restricted to the European continent, especially in the lower troposphere. In contrast to temperature, specific humidity anomalies do not change sign in the tropopause region. The strongest anomalies, exceeding $30 \%$, are found at the altitude of weakest temperature anomalies (near $270 \mathrm{hPa}$ ). In the (generally) very dry stratosphere the specific humidity anomalies decrease rapidly and no statistically significant signal of blocking is found above about $150 \mathrm{hPa}$.

For extended summer, temperature and relative specific humidity anomaly composites during blocked days in the 
(a)

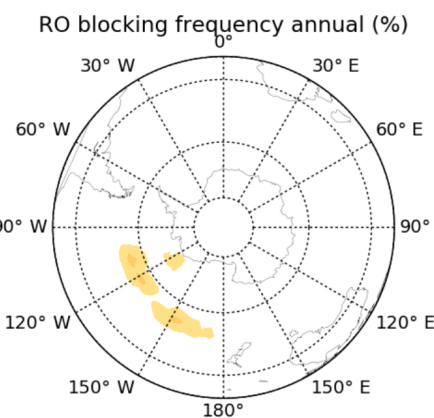

RO blocking frequency MAM (\%)

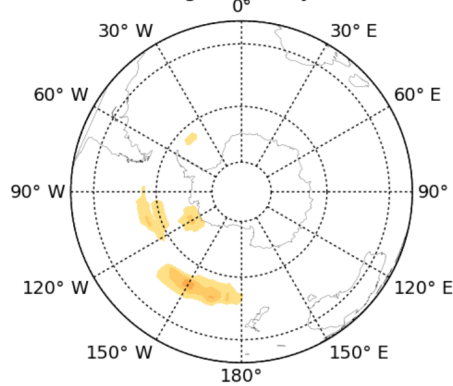

RO blocking frequency JJA (\%)
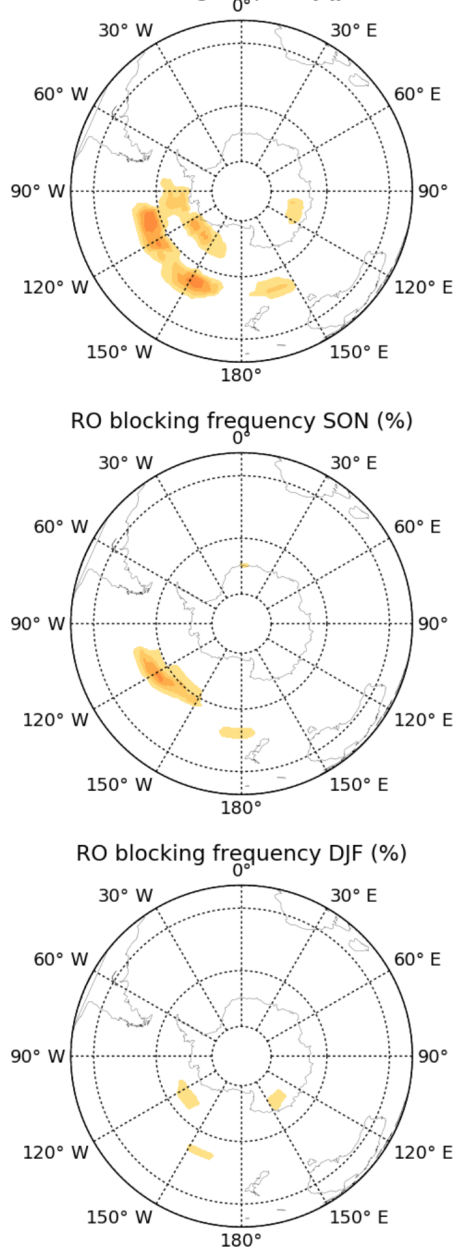

(b)

ERA-Interim blocking frequency annual (\%)

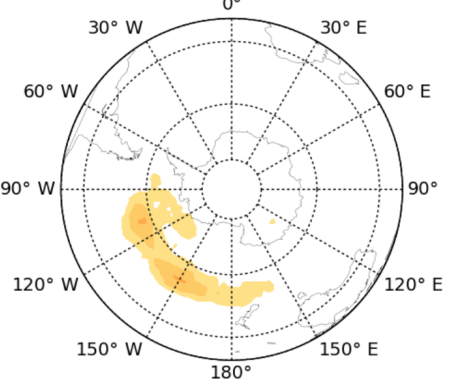

ERA-Interim blocking frequency MAM (\%)

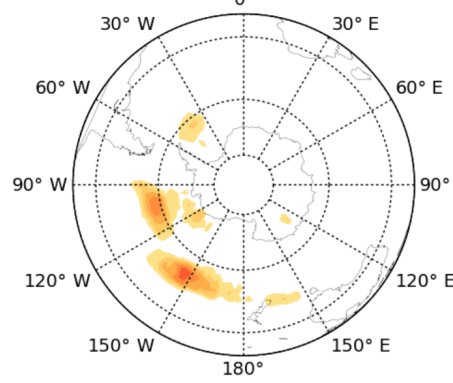

ERA-Interim blocking frequency JJA (\%)

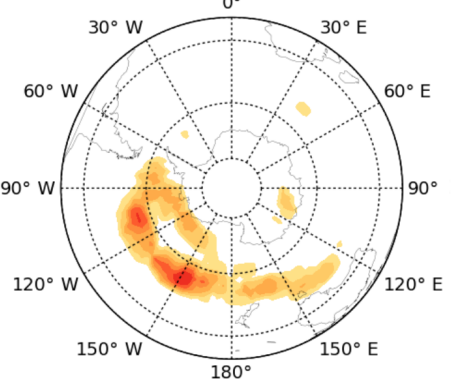

ERA-Interim blocking frequency SON (\%)

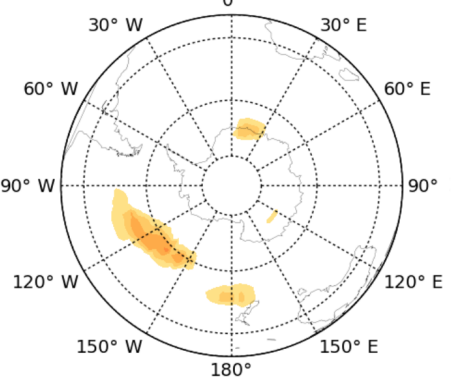

ERA-Interim blocking frequency DJF (\%)

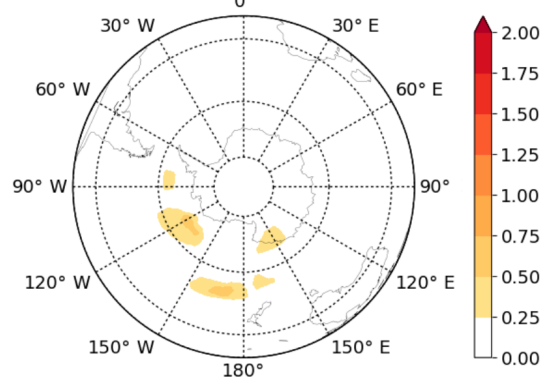

(c)

RO - ERA-Interim blocking frequency annual (\%)

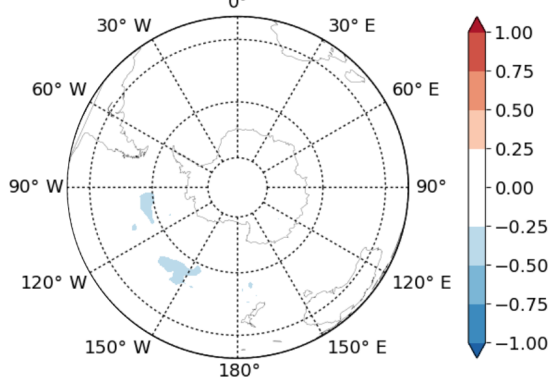

RO - ERA-Interim blocking frequency MAM (\%)

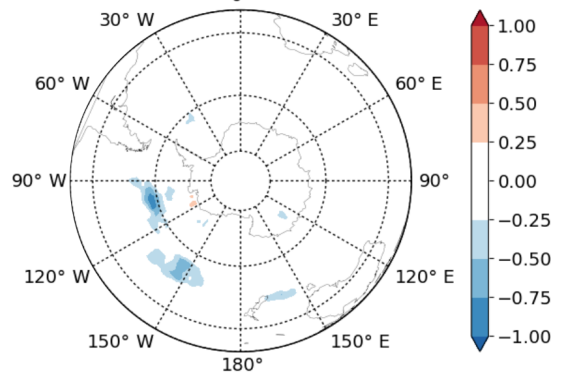

RO - ERA-Interim blocking frequency JJA (\%)

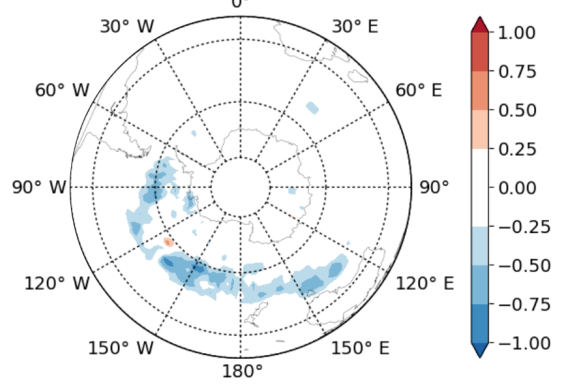

RO - ERA-Interim blocking frequency SON (\%)

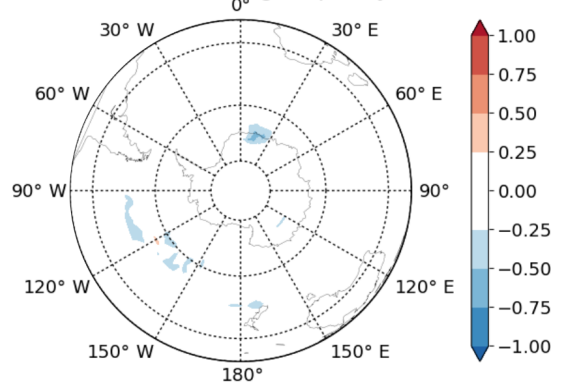

RO - ERA-Interim blocking frequency DJF (\%)

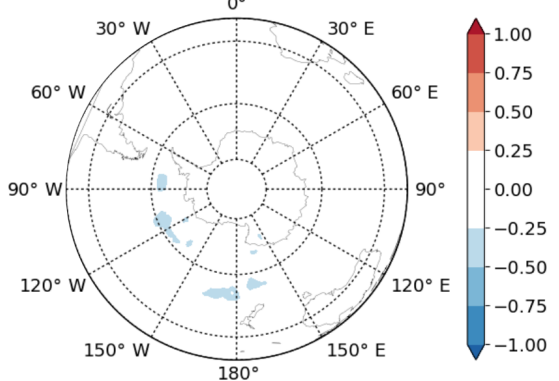

Figure 4. As Fig. 3 but for the Southern Hemisphere. Note the different colour bar ranges compared to Fig. 3. 
(a)

(b)

\section{North Atlantic region, extended winter (NDJFM)}
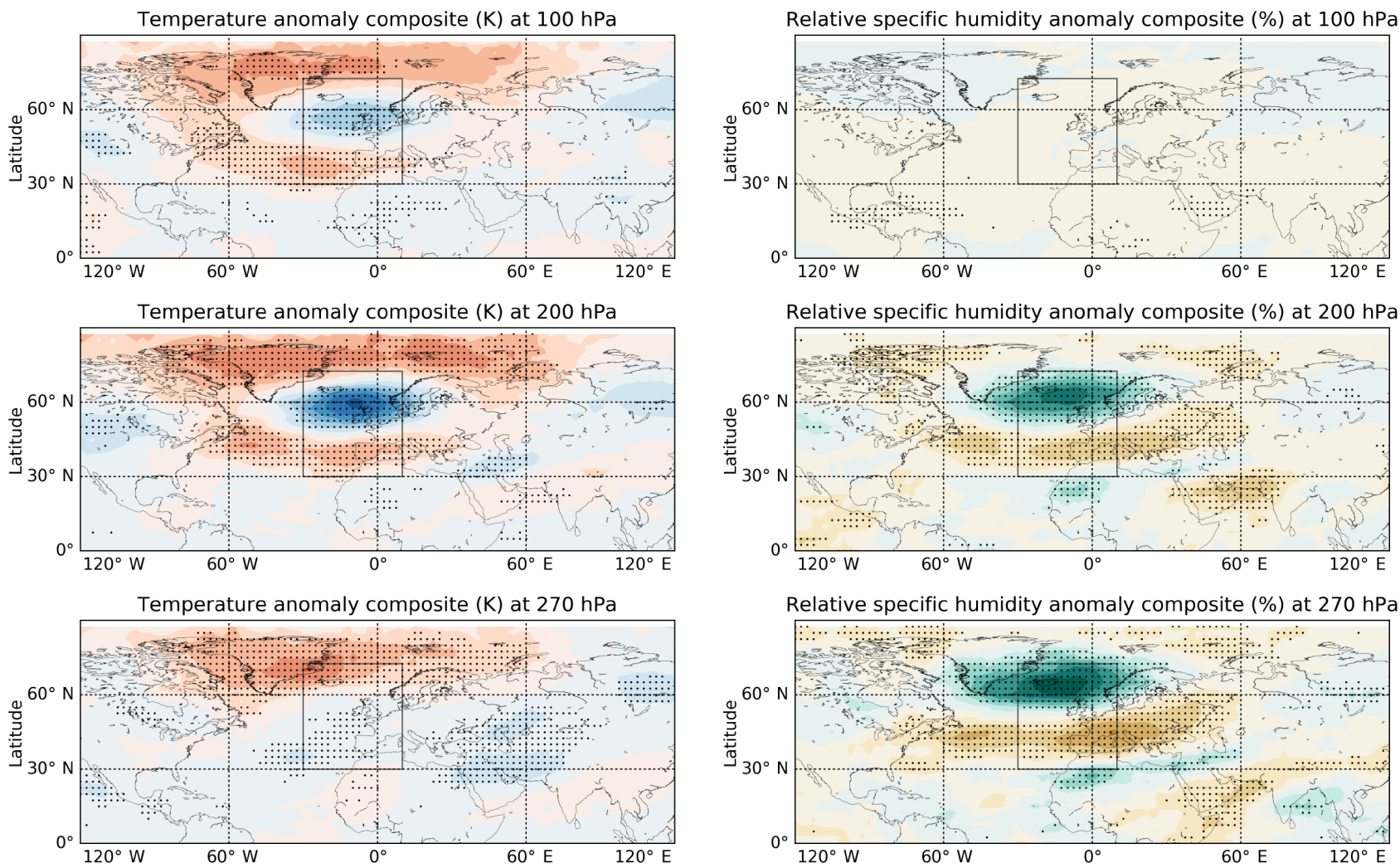

Relative specific humidity anomaly composite (\%) at $270 \mathrm{hPa}$
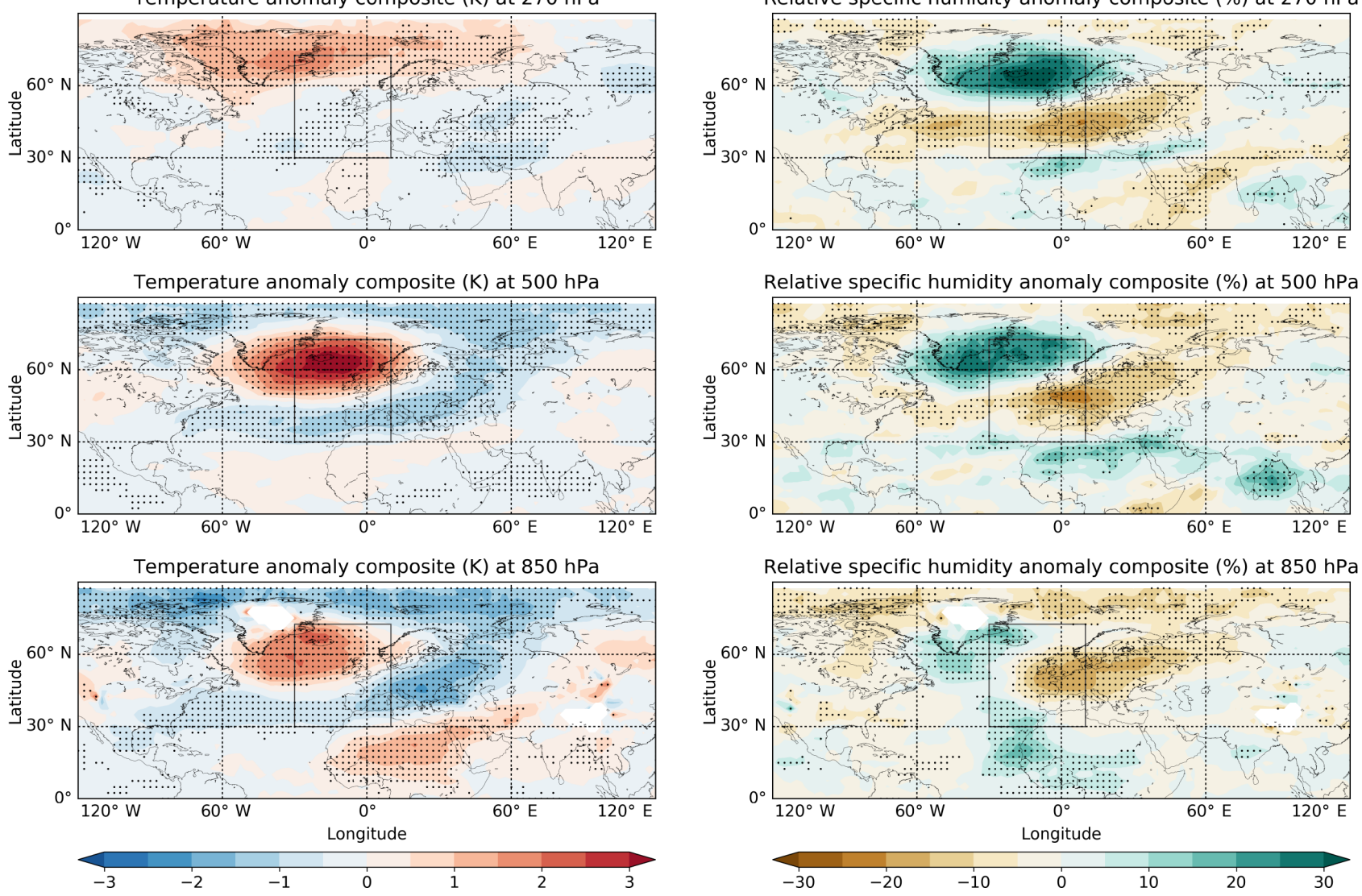

Figure 5. Composites of (a) temperature anomalies and (b) relative specific humidity anomalies during blocked days in the North Atlantic region between $30^{\circ} \mathrm{W}-10^{\circ} \mathrm{E}$ and $30-72.5^{\circ} \mathrm{N}$ (grey box; 267 days in total). Shown is the northern hemispheric extended winter (NDJFM) season. Hatched regions denote statistical significance at the 5th and 95th percentile levels. 
(a)

(b)

\section{North Atlantic region, extended summer (MJJAS)}
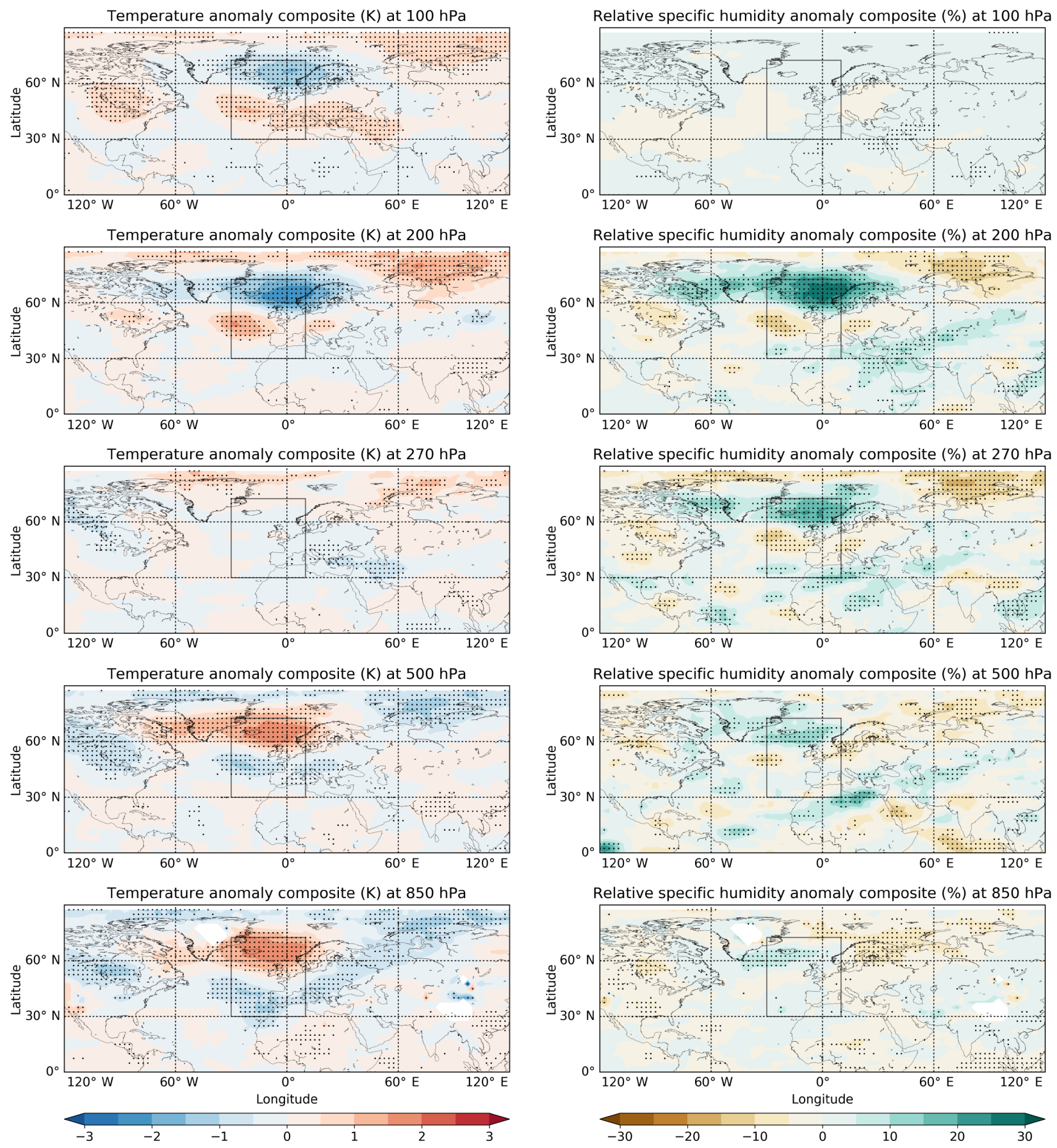

Figure 6. As Fig. 5 but for the extended summer (MJJAS) season (186 days in total).

Euro-Atlantic region (Fig. 6) are about $1 \mathrm{~K}$ and $10 \%$ lower compared to respective anomalies in winter. Moreover, the band of cold air surrounding the central warm anomaly is less distinct in summer. At $500 \mathrm{hPa}$, where the feature is clearest in winter, large regions, especially over north-eastern Eu- rope, are not statistically significantly colder during blocked conditions. This indicates that cold advection from the north is less important during summer blocking. Specific humidity anomalies during summer blocking in this region are not statistically significant in most of the troposphere. Stronger 
(a)

\section{North Pacific region, extended winter (NDJFM)}
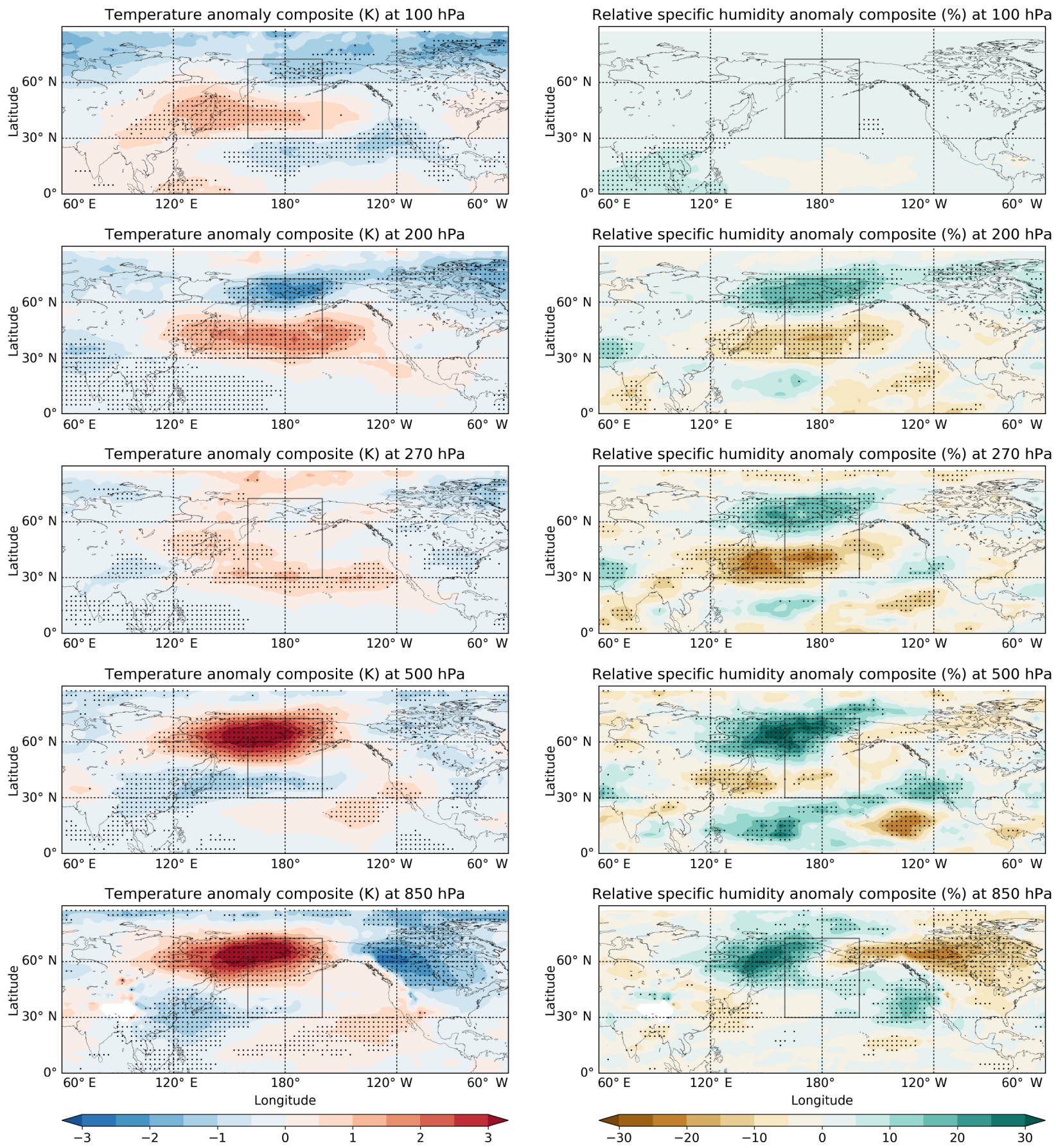

Figure 7. As Fig. 5 but for blocking in the North Pacific region between $160^{\circ} \mathrm{E}-160^{\circ} \mathrm{W}$ and $30-72.5^{\circ} \mathrm{N}$ (191 days in total).

anomalies are only visible near the tropopause and above, between 270 and $200 \mathrm{hPa}$.

In the North Pacific blocking region during extended winter (Fig. 7), the main feature in temperature is again a strong positive anomaly in the troposphere. Compared to the North
Atlantic region the anomaly is stronger in the lower troposphere below $500 \mathrm{hPa}$, while the negative anomaly in the lower stratosphere is slightly weaker. The tropospheric cold anomalies are limited to east and south-west of the blocking region with the coldest temperatures found over the north- 
west of the North American continent. In the lower stratosphere the warm anomaly is limited to the south of the blocking region, creating a distinct dipole feature near the $200 \mathrm{hPa}$ pressure level.

Specific humidity anomalies are strongest in the lower and middle troposphere between 850 and $500 \mathrm{hPa}$ and about $10 \%$ lower than in the North Atlantic region between 270 and $200 \mathrm{hPa}$. At 270 and $200 \mathrm{hPa}$ a clear dipole similar to the $200 \mathrm{hPa}$ temperature anomaly can be found. Above $200 \mathrm{hPa}$ the influence of blocking on atmospheric humidity decreases and hardly any significant signal is found.

For the SH (Fig. 8) we show blocking effects in the East Pacific region. Similar to the NH, both temperature and specific humidity anomalies are clearly shifted to the west of the blocking region in the lower troposphere. The strongest temperature anomalies during blocking, clearly exceeding $3 \mathrm{~K}$, are found in the lowermost part of the troposphere. Towards the tropopause the anomalies decrease and again change sign near $270 \mathrm{hPa}$. The lowest temperature anomalies below $-3 \mathrm{~K}$ are located near $200 \mathrm{hPa}$, similar to the $\mathrm{NH}$. Above, the influence of blocking on temperature decreases. The tropospheric cold anomalies surrounding the blocking region are less distinct in the SH. These results suggest that cold advection plays a less important role in the $\mathrm{SH}$ due to the stronger zonal flow. A clear band of negative temperature anomalies is only visible at $500 \mathrm{hPa}$, while at $850 \mathrm{hPa}$ the strongest cold anomalies are restricted to downstream of the blocking region. Compared to the $\mathrm{NH}$ a stronger second temperature maximum appears north-east of the blocking region.

Specific humidity anomalies in the SH show notably more variation than in the $\mathrm{NH}$. Throughout the entire troposphere relative wet and dry anomalies exceed $30 \%$. The anomalies spread in a wave-like pattern from the blocking region to the north-east, which is most distinct near the tropopause at about $270 \mathrm{hPa}$. In the lower stratosphere the specific humidity anomalies again decrease rapidly.

In summary, we find similar effects of blocking on atmospheric temperature and specific humidity anomalies in the different investigated regions in both hemispheres. Largest differences in amplitude appear between the seasons, while the SH shows a more complex signature of blocking, especially in specific humidity. For all cases strong positive temperature anomalies are found in the lower to middle troposphere and a maximum negative anomaly in the lower stratosphere at about $200 \mathrm{hPa}$. Specific humidity anomalies are strongest higher up between 270 and $200 \mathrm{hPa}$ except in the North Pacific region, where the largest anomalies are found at the $500 \mathrm{hPa}$ level.

\section{Summary, conclusions, and outlook}

We presented the first comprehensive analysis of global atmospheric blocking based on GPS RO observations. We used one decade of RO measurements from September 2006 to
August 2016 to derive blocking climatologies and to investigate blocking impacts on vertically resolved atmospheric temperature and specific humidity fields. We investigated the representation of main blocking regions in the $\mathrm{NH}$ and $\mathrm{SH}$ for different seasons. The impact of blocking on vertically resolved temperature and humidity was examined based on anomaly composites and its significance was tested.

Our results show that RO data are well suited for blocking detection. RO correctly resolves the blocking regions in both hemispheres, also capturing the seasonal blocking variability. Average blocking episodes in the $\mathrm{NH}$ are found to persist for 4 days and have a longitudinal extent of $34^{\circ}$. In the $\mathrm{SH}$ blocking is less persistent and lasts on average 2.5 days, with a typical extent of $23^{\circ}$ in longitude.

The impact of blocking on temperature and specific humidity is found to be statistically significant throughout the troposphere and lower stratosphere in both hemispheres. During extended winter a strong positive temperature anomaly exceeding $3 \mathrm{~K}$ is found in the centre of the blocking area, slightly shifted to the west at lower altitudes. Above about $500 \mathrm{hPa}$ this anomaly decreases until it changes sign above the climatological tropopause near $270 \mathrm{hPa}$. In the lower stratosphere, blocking leads to a negative temperature anomaly below $-3 \mathrm{~K}$ near $200 \mathrm{hPa}$. Higher up the influence of blocking on temperature decreases. In the troposphere, cold anomalies surround the central warm anomaly, indicating the effect of advection of cold air from the polar region by the anticyclonic motion around blocking highs, which is in general agreement with findings by Bieli et al. (2015). In the lower stratosphere this anomaly also changes sign and appears as anomalously warm region equatorward of the block. Summer temperature anomalies are similar to those in winter but notably weaker in amplitude of up to $50 \%$. In addition, the advection of cold air plays a less important role, leading to less distinct negative anomalies in the troposphere.

Specific humidity anomalies show a similar behaviour as temperature in the troposphere. In the North Atlantic region, a central wet anomaly is surrounded by dry anomalies on the eastern and equatorward side. However, the anomalies do not change sign at the tropopause, leading to inverse patterns of temperature and specific humidity anomalies in the lower stratosphere. This behaviour of temperature and specific humidity at the tropopause level has recently also been noted by Sitnov et al. (2017). Above about $200 \mathrm{hPa}$, the influence of blocking on specific humidity is found to decrease rapidly. In the south-east Pacific region, specific humidity anomalies are generally stronger than in the $\mathrm{NH}$ and show a wave-like pattern with positive and negative anomalies alternating from the south-west to the north-east due to a stronger zonal flow.

Our findings highlight the main blocking regions in both hemispheres and the effect of blocking in these regions on atmospheric temperature and specific humidity using GPS RO observations. The slight underestimation of blocking frequencies in RO compared to three different reanalyses, ERA-Interim, JRA-55, and MERRA-2, is most probably due 
(a)

\section{East Pacific region, extended winter (MJJAS)}

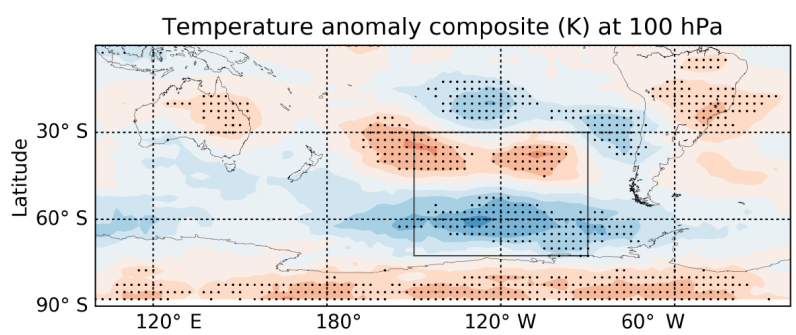

Temperature anomaly composite $(\mathrm{K})$ at $200 \mathrm{hPa}$

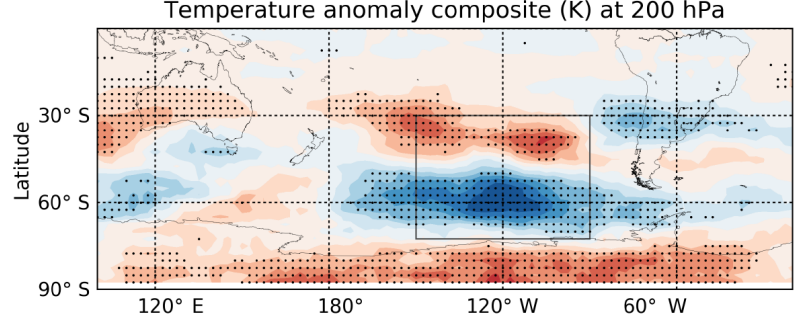

Temperature anomaly composite (K) at $270 \mathrm{hPa}$

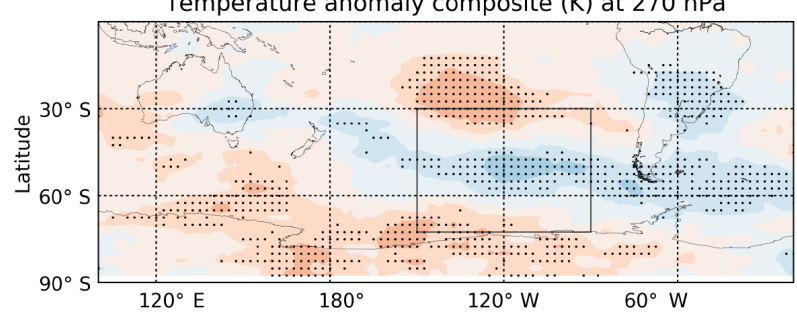

Temperature anomaly composite (K) at $500 \mathrm{hPa}$
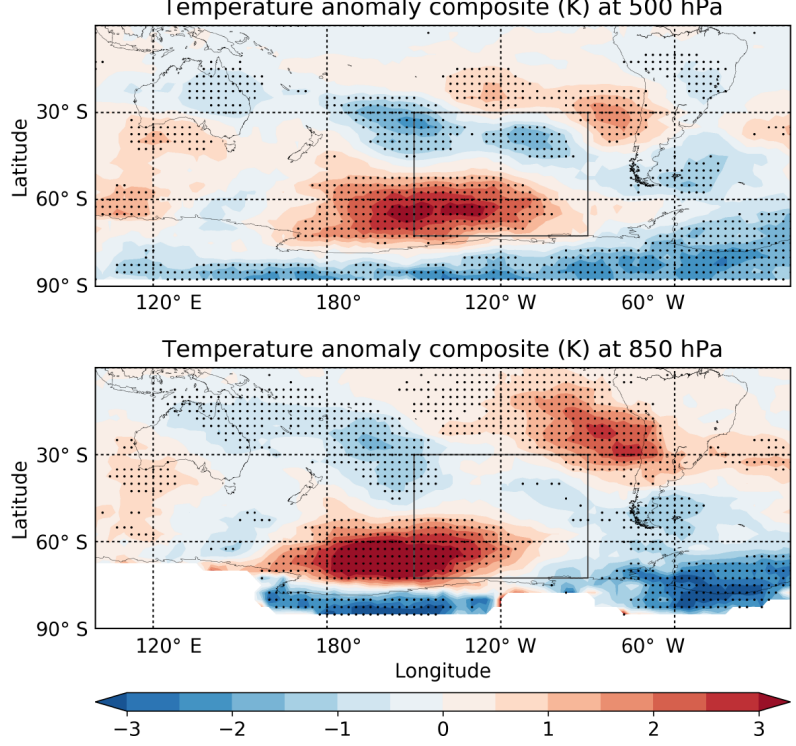

Relative specific humidity anomaly composite (\%) at $100 \mathrm{hPa}$

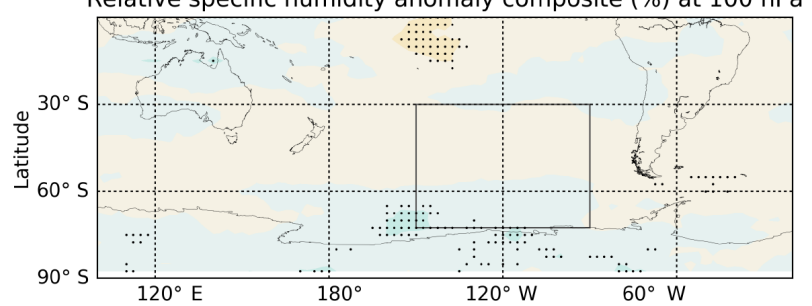

Relative specific humidity anomaly composite (\%) at $200 \mathrm{hPa}$
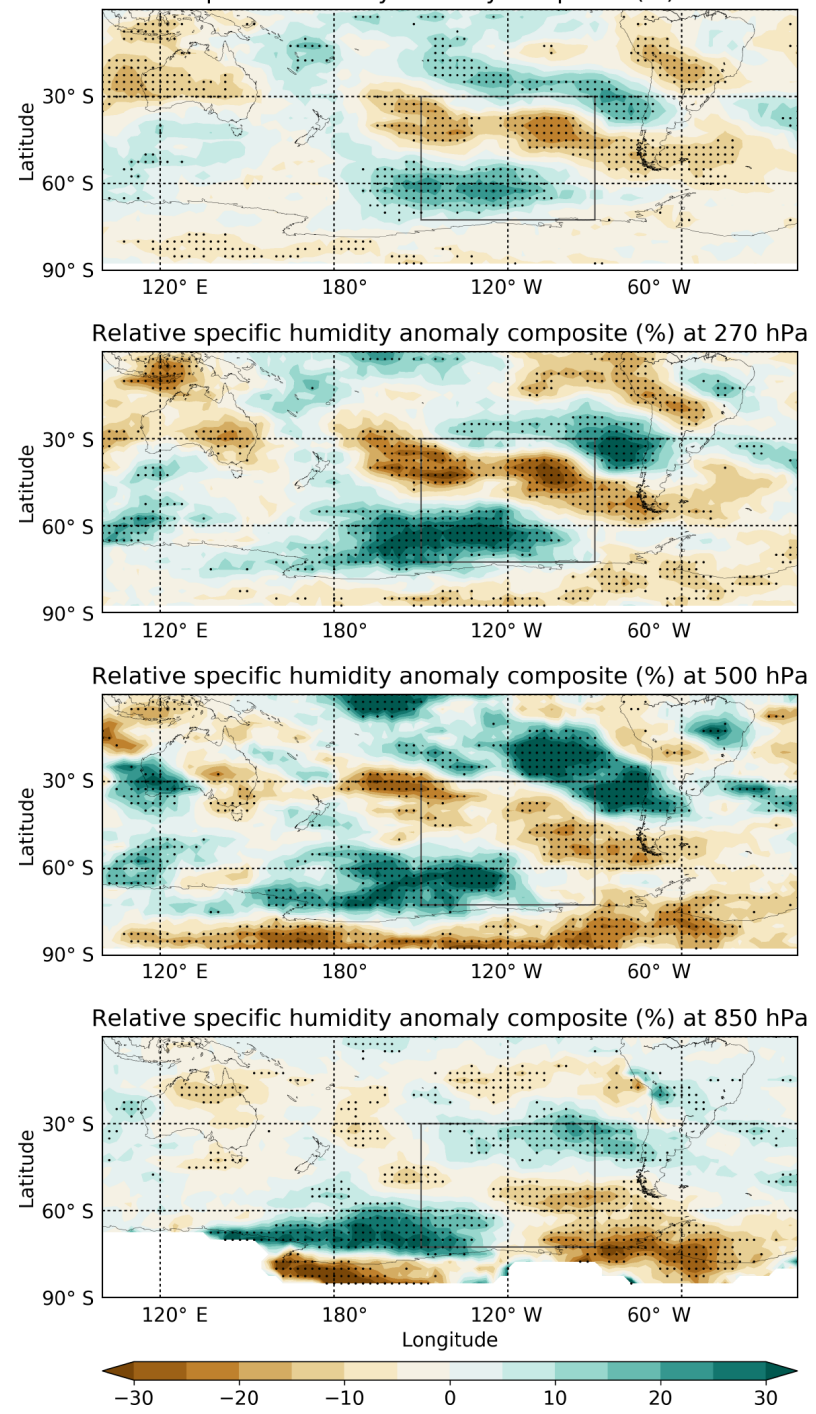

Figure 8. As Fig. 5 but for the southern hemispheric extended winter (MJJAS) shown for blocking in the East Pacific region between $150-90^{\circ} \mathrm{W}$ and $72.5-30^{\circ} \mathrm{S}$ (81 days in total).

to a too-sparse measurement density. Future RO missions, like the FORMOSAT-7/COSMIC-2 constellation, and the exploitation of signals from more Global Navigation Satellite System (GNSS) constellations, like the European Galileo, the Russian GLONASS, and the Chinese BeiDou, are expected to significantly increase the number of RO events, promising to overcome this undersampling and allowing an 
even better performance of RO data in blocking representation (Yue et al., 2014).

RO measurements provide a mostly independent, comprehensive observation-based record of known accuracy (Parker, 2016) for the detection and analysis of atmospheric blocking complementing reanalyses and models. The high vertical resolution of the $\mathrm{RO}$ measurements makes them ideal for investigating the atmospheric structure during blocking episodes. This will allow to gain a better understanding of the development of blocking related extreme events, like heat waves and cold spells, flooding, or droughts, in the future.

Code availability. The analysis was carried out in Python 2.7, and the code is available upon request from L. Brunner (lukas.brunner@uni-graz.at).

Data availability. We used geopotential height fields from three reanalyses: the European Centre for Medium-Range Weather Forecasts, ERA-Interim (ECMWF, 2017), the Japan Meteorological Agency, JRA-55 (JMA, 2017), and the Global Modeling and Assimilation Office (GMAO, 2015).

The gridded RO data used in this study are available on request from L. Brunner (lukas.brunner@uni-graz.at) and will be provided publicly soon.

Author contributions. LB collected the data, performed the analyses, created the figures, and wrote the manuscript. AKS provided guidance on all aspects of the study, contributed to the text, and advised on this work.

Competing interests. The authors declare that they have no conflict of interest.

Special issue statement. This article is part of the special issue "Observing Atmosphere and Climate with Occultation Techniques - Results from the OPAC-IROWG 2016 Workshop". It is a result of the International Workshop on Occultations for Probing Atmosphere and Climate, Leibnitz, Austria, 8-14 September 2016.

Acknowledgements. The authors thank Paolo Davini for helpful advice and discussions and Emil Fridolin Hohmann for reminding us what is really important. ECMWF, JMA, and NASA are acknowledged for providing their reanalyses as detailed in Sect. 7. UCAR/CDAAC (Boulder, CO, USA) is acknowledged for access to its RO phase and orbit data; the WEGC processing team members (Marc Schwärz, Florian Ladstädter, Barbara Angerer) are thanked for providing the OPSv5.6 RO data. This work was funded by the Austrian Science Fund (FWF) under research grant W 1256-G15 (Doctoral Programme Climate Change - Uncertainties, Thresholds and Coping Strategies). Lukas Brunner was financially supported by a Marietta Blau Grant by the Austrian Exchange Service (OeAD), financed by funds from the Austrian Federal Ministry of Science, Research and Economy (BMWFW). The Center for International Climate Research Oslo (CICERO, Norway) is acknowledged for hosting Lukas Brunner during part of the work. The authors thank all contributors to Python and $\mathrm{LTT}_{\mathrm{E}} \mathrm{X}$, which were used throughout the work.

The authors thank the editor Axel von Engeln for handling the manuscript and two anonymous reviewers for their helpful comments.

Edited by: Axel von Engeln

Reviewed by: two anonymous referees

\section{References}

Angerer, B., Ladstädter, F., Scherllin-Pirscher, B., Schwärz, M., Steiner, A. K., Foelsche, U., and Kirchengast, G.: Quality Aspects of the Wegener Center Multi-Satellite GPS Radio Occultation Record OPSv5.6, Atmos. Meas. Tech. Discuss., https://doi.org/10.5194/amt-2017-225, in review, 2017.

Anstey, J. A., Davini, P., Gray, L. J., Woollings, T. J., Butchart, N., Cagnazzo, C., Christiansen, B., Hardiman, S. C., Osprey, S. M., and Yang, S.: Multi-model analysis of Northern Hemisphere winter blocking: Model biases and the role of resolution, J. Geophys. Res., 118, 3956-3971, https://doi.org/10.1002/jgrd.50231, 2013.

Anthes, R. A.: Exploring Earth's atmosphere with radio occultation: contributions to weather, climate and space weather, Atmos. Meas. Tech., 4, 1077-1103, https://doi.org/10.5194/amt-4-10772011, 2011.

Barnes, E. A., Slingo, J., and Woollings, T.: A methodology for the comparison of blocking climatologies across indices, models and climate scenarios, Clim. Dynam., 38, 2467-2481, https://doi.org/10.1007/s00382-011-1243-6, 2012.

Barriopedro, D., García-Herrera, R., Lupo, A. R., and Hernández, E.: A climatology of northern hemisphere blocking, J. Climate, 19, 1042-1063, https://doi.org/10.1175/JCLI3678.1, 2006.

Barriopedro, D., García-Herrera, R., and Trigo, R. M.: Application of blocking diagnosis methods to General Circulation Models. Part I: a novel detection scheme, Clim. Dynam., 35, 1373-1391, https://doi.org/10.1007/s00382-010-0767-5, 2010.

Barriopedro, D., Fischer, E. M., Luterbacher, J., Trigo, R. M., and García-Herrera, R.: The Hot Summer of 2010: Redrawing the Temperature Record Map of Europe, Science, 332, 220-224, https://doi.org/10.1126/science.1201224, 2011.

Berrisford, P., Hoskins, B. J., and Tyrlis, E.: Blocking and Rossby Wave Breaking on the Dynamical Tropopause in the Southern Hemisphere, J. Atmos. Sci., 64, 2881-2898, https://doi.org/10.1175/JAS3984.1, 2007.

Bieli, M., Pfahl, S., and Wernli, H.: A Lagrangian investigation of hot and cold temperature extremes in Europe, Q. J. Roy. Meteor. Soc., 141, 98-108, https://doi.org/10.1002/qj.2339, 2015.

Brunner, L., Steiner, A. K., Scherllin-Pirscher, B., and Jury, M. W.: Exploring atmospheric blocking with GPS radio occultation observations, Atmos. Chem. Phys., 16, 4593-4604, https://doi.org/10.5194/acp-16-4593-2016, 2016.

Brunner, L., Hegerl, G. C., and Steiner, A. K.: Connecting atmospheric blocking to European temperature extremes in spring, 
J. Climate, 30, 585-594, https://doi.org/10.1175/JCLI-D-160518.1, 2017.

Buehler, T., Raible, C. C., and Stocker, T. F.: The relationship of winter season North Atlantic blocking frequencies to extreme cold or dry spells in the ERA-40, Tellus A, 63, 212-222, https://doi.org/10.1111/j.1600-0870.2010.00492.x, 2011.

Cardinali, C.: Monitoring the observation impact on the shortrange forecast, Q. J. Roy. Meteor. Soc., 135, 239-250, https://doi.org/10.1002/qj.366, 2009.

Carrera, M., Higgins, R., and Kousky, V.: Downstream Weather Impacts Associated with Atmospheric Blocking over the Northeast Pacific, J. Climate, 17, 4823-4839, https://doi.org/10.1175/JCLI3237.1, 2004.

Cattiaux, J., Vautard, R., Cassou, C., Yiou, P., Masson-Delmotte, V., and Codron, F.: Winter 2010 in Europe: A cold extreme in a warming climate, Geophys. Res. Lett., 37, L20704, https://doi.org/10.1029/2010GL044613, 2010.

Christensen, J. H., Kumar, K. K., Aldrian, E., An, S.-I., Cavalcanti, I., de Castro, M., Dong, W., Goswami, P., Hall, A., Kanyanga, J., Kitoh, A., Kossin, J., Lau, N.-C., Renwick, J., Stephenson, D., Xie, S.-P., and Zhou, T.: Climate Phenomena and their Relevance for Future Regional Climate Change, in: Climate Change 2013: The Physical Science Basis. Contribution of Working Group I to the Fifth Assessment Report of the Intergovernmental Panel on Climate Change, edited by: Stocker, T., Qin, D., Plattner, G.-K., Tignor, M., Allen, S., Boschung, J., Nauels, A., Xia, Y., Bex, V., and Midgley, P., 1217-1308, Cambridge University Press, Cambridge, UK and New York, NY, USA, 2013.

Cowan, T., van Rensch, P., Purich, A., and Cai, W.: The Association of Tropical and Extratropical Climate Modes to Atmospheric Blocking across Southeastern Australia, J. Climate, 26, 75557569, https://doi.org/10.1175/JCLI-D-12-00781.1, 2013.

Croci-Maspoli, M., Schwierz, C., and Davies, H. C.: A Multifaceted Climatology of Atmospheric Blocking and Its Recent Linear Trend, J. Climate, 20, 633-649, https://doi.org/10.1175/JCLI4029.1, 2007.

Damião Mendes, M. C. and Cavalcanti, I. F. A.: The relationship between the Antarctic oscillation and blocking events over the South Pacific and Atlantic Oceans, Int. J. Climatol., 34, 529-544, https://doi.org/10.1002/joc.3729, 2014.

D’Andrea, F., Tibaldi, S., Blackburn, M., Boer, G., Déqué, M., Dix, M. R., Dugas, B., Ferranti, L., Iwasaki, T., Kitoh, A., Pope, V., Randall, D., Roeckner, E., Strauss, D., Stern, W., Van den Dool, H., and Williamson, D.: Northern Hemisphere atmospheric blocking as simulated by 15 atmospheric general circulation models in the period 1979-1988, Clim. Dynam., 14, 385-407, https://doi.org/10.1007/s003820050230, 1998.

Davini, P. and D'Andrea, F.: Northern Hemisphere Atmospheric Blocking Representation in Global Climate Models: Twenty Years of Improvements?, J. Climate, 29, 8823-8840, https://doi.org/10.1175/JCLI-D-16-0242.1, 2016.

Davini, P., Cagnazzo, C., Gualdi, S., and Navarra, A.: Bidimensional diagnostics, variability, and trends of Northern Hemisphere blocking, J. Climate, 25, 6496-6509, https://doi.org/10.1175/JCLI-D-12-00032.1, 2012.

Davini, P., Cagnazzo, C., Fogli, P. G., Manzini, E., Gualdi, S., and Navarra, A.: European blocking and Atlantic jet stream variability in the NCEP/NCAR reanalysis and the
CMCC-CMS climate model, Clim. Dynam., 43, 71-85, https://doi.org/10.1007/s00382-013-1873-y, 2014.

de Adana, F. J. S. and Colucci, S. J.: Southern Hemisphere Blocking Onsets Associated with Upper-Tropospheric Divergence Anomalies, J. Atmos. Sci., 62, 1614-1625, https://doi.org/10.1175/JAS3421.1, 2005.

Dee, D. P., Uppala, S. M., Simmons, A. J., Berrisford, P., Poli, P., Kobayashi, S., Andrae, U., Balmaseda, M. A., Balsamo, G., Bauer, P., Bechtold, P., Beljaars, A. C. M., van de Berg, L., Bidlot, J., Bormann, N., Delsol, C., Dragani, R., Fuentes, M., Geer, A. J., Haimberger, L., Healy, S. B., Hersbach, H., Hólm, E. V., Isaksen, L., Kållberg, P., Köhler, M., Matricardi, M., McNally, A. P., Monge-Sanz, B. M., Morcrette, J.-J., Park, B.-K., Peubey, C., de Rosnay, P., Tavolato, C., Thépaut, J.-N., and Vitart, F.: The ERA-Interim reanalysis: configuration and performance of the data assimilation system, Q. J. Roy. Meteor. Soc., 137, 553-597, https://doi.org/10.1002/qj.828, 2011.

Dee, D. P., Fasullo, J., Shea, D., Walsh, J., and National Center for Atmospheric Research Staff: The Climate Data Guide: Atmospheric Reanalysis: Overview \& Comparison Tables, available at: https://climatedataguide.ucar.edu/climate-data/ atmospheric-reanalysis-overview-comparison-tables (last access: 15 November 2017), 2016.

de la Torre, A. and Alexander, P.: Gravity waves above Andes detected from GPS radio occultation temperature profiles: Mountain forcing?, Geophys. Res. Lett., 32, L17815, https://doi.org/10.1029/2005GL022959, 2005.

Dunn-Sigouin, E. and Son, S.-W.: Northern Hemisphere blocking frequency and duration in the CMIP5 models, J. Geophys. Res.Atmos, 118, 1179-1188, https://doi.org/10.1002/jgrd.50143, 2013.

Ebita, A., Kobayashi, S., Ota, Y., Moriya, M., Kumabe, R., Onogi, K., Harada, Y., Yasui, S., Miyaoka, K., Takahashi, K., Kamahori, H., Kobayashi, C., Endo, H., Soma, M., Oikawa, Y., and Ishimizu, T.: The Japanese 55-year Reanalysis "JRA-55": An Interim Report, SOLA, 7, 149-152, https://doi.org/10.2151/sola.2011-038, 2011.

European Centre for Medium-Range Weather Forecasts (ECMWF): ERA-Interim: ECMWF Reanalysis Interim, available at: http:// apps.ecmwf.int/datasets/data/interim-full-daily/levtype=pl/, last access: 1 March 2017.

Favre, A. and Gershunov, A.: Extra-tropical cyclonic/anticyclonic activity in North-Eastern Pacific and air temperature extremes in Western North America, Clim. Dynam., 26, 617-629, https://doi.org/10.1007/s00382-005-0101-9, 2006.

Foelsche, U., Scherllin-Pirscher, B., Ladstädter, F., Steiner, A. K., and Kirchengast, G.: Refractivity and temperature climate records from multiple radio occultation satellites consistent within $0.05 \%$, Atmos. Meas. Tech., 4, 2007-2018, https://doi.org/10.5194/amt-4-2007-2011, 2011.

Fujiwara, M., Wright, J. S., Manney, G. L., Gray, L. J., Anstey, J., Birner, T., Davis, S., Gerber, E. P., Harvey, V. L., Hegglin, M. I., Homeyer, C. R., Knox, J. A., Krüger, K., Lambert, A., Long, C. S., Martineau, P., Molod, A., Monge-Sanz, B. M., Santee, M. L., Tegtmeier, S., Chabrillat, S., Tan, D. G. H., Jackson, D. R., Polavarapu, S., Compo, G. P., Dragani, R., Ebisuzaki, W., Harada, Y., Kobayashi, C., McCarty, W., Onogi, K., Pawson, S., Simmons, A., Wargan, K., Whitaker, J. S., and Zou, C.-Z.: Introduction to the SPARC Reanalysis Intercomparison 
Project (S-RIP) and overview of the reanalysis systems, Atmos. Chem. Phys., 17, 1417-1452, https://doi.org/10.5194/acp17-1417-2017, 2017.

Galarneau Jr., T. J., Hamill, T. M., Dole, R. M., and Perlwitz, J.: A Multiscale Analysis of the Extreme Weather Events over Western Russia and Northern Pakistan during July 2010, Mon. Weather Rev., 140, 1639-1664, https://doi.org/10.1175/MWRD-11-00191.1, 2012.

García-Herrera, R., Diaz, J., Trigo, R. M., Luterbacher, J., and Fischer, E. M.: A Review of the European Summer Heat Wave of 2003, Crit. Rev. Env. Sci. Tec., 40, https://doi.org/10.1080/10643380802238137, 2010.

Gelaro, R., McCarty, W., Suárez, M. J., Todling, R., Molod, A., Takacs, L., Randles, C., Darmenov, A., Bosilovich, M. G., Reichle, R., Wargan, K., Coy, L., Cullather, R., Draper, C., Akella, S., Buchard, V., Conaty, A., da Silva, A., Gu, W., Kim, G.-K., Koster, R., Lucchesi, R., Merkova, D., Nielsen, J. E., Partyka, G., Pawson, S., Putman, W., Rienecker, M., Schubert, S. D., Sienkiewicz, M., and Zhao, B.: The Modern-Era Retrospective Analysis for Research and Applications, Version 2 (MERRA-2), J. Climate, 30, 5419-5454, https://doi.org/10.1175/JCLI-D-160758.1, 2017.

Gilbert, N.: Russia counts environmental cost of wildfires, Nature News: Briefing, https://doi.org/10.1038/news.2010.404, 2010.

Gleisner, H., Thejll, P., Christiansen, B., and Nielsen, J. K.: Recent global warming hiatus dominated by low-latitude temperature trends in surface and troposphere data, Geophys. Res. Lett., 42, 510-517, https://doi.org/10.1002/2014GL062596, 2015.

Global Modeling and Assimilation Office (GMAO): MERRA-2 inst6_3d_ana_Np: 3d, 6-Hourly, Instantaneous, Pressure-Level, Analysis, Analyzed Meteorological Fields V5.12.4, Greenbelt, MD, USA, Goddard Earth Sciences Data and Information Services Center (GES DISC), https://doi.org/10.5067/A7S6XP56VZWS, (last access: 18 November 2016), 2015.

Gorbunov, M. E., Benzon, H.-H., Jensen, A. S., Lohmann, M. S., and Nielsen, A. S.: Comparative analysis of radio occultation processing approaches based on Fourier integral operators, Radio Sci., 39, RS6004, https://doi.org/10.1029/2003RS002916, 2004.

Hajj, G. A., Kursinski, E. R., Romans, L. J., Bertiger, W. I., and Leroy, S. S.: A technical description of atmospheric sounding by GPS occultation, J. Atmos. Sol.-Terr. Phy., 64, 451-469, https://doi.org/10.1016/S1364-6826(01)00114-6, 2002.

Healy, S. B. and Thépaut, J. N.: Assimilation experiments with CHAMP GPS radio occultation measurements, Q. J. Roy. Meteor. Soc., 132, 605-623, https://doi.org/10.1256/qj.04.182, 2006.

Ho, S.-P., Hunt, D., Steiner, A. K., Mannucci, A. J., Kirchengast, G., Gleisner, H., Heise, S., von Engeln, A., Marquardt, C., Sokolovskiy, S., Schreiner, W., Scherllin-Pirscher, B., Ao, C., Wickert, J., Syndergaard, S., Lauritsen, K., Leroy, S., Kursinski, E. R., Kuo, Y.-H., Foelsche, U., Schmidt, T., and Gorbunov, M.: Reproducibility of GPS radio occultation data for climate monitoring: Profile-to-profile inter-comparison of CHAMP climate records 2002 to 2008 from six data centers, J. Geophys. Res., 117, D18111, https://doi.org/10.1029/2012JD017665, 2012.

IPCC: Climate Change 2013: The Physical Science Basis. Contribution of Working Group I to the Fifth Assessment Report of the Intergovernmental Panel on Climate Change, edited by: Stocker,
T. F., Qin, D., Plattner, G.-K., Tignor, M., Allen, S. K., Boschung, J., Nauels, A., Xia, Y., Bex, V., and Midgley, P. M., Cambridge, UK and New York, NY, USA, 1535 pp., 2013.

Japan Meteorological Agency (JMA): JRA-55: Japanese 55-year Reanalysis, available at: http://jra.kishou.go.jp/JRA-55/index_ en.html, last access: 27 January 2017.

Kobayashi, S., Ota, Y., Harada, Y., Ebita, A., Moriya, M., Onoda, H., Onogi, K., Kamahori, H., Kobayashi, C., Endo, H., Miyaoka, K., and Takahashi, K.: The JRA-55 Reanalysis: General Specifications and Basic Characteristics, J. Meteorol. Soc. Jpn., 93, 5-48, https://doi.org/10.2151/jmsj.2015-001, 2015.

Kursinski, E. R., Hajj, G. A., Schofield, J. T., Linfield, R. P., and Hardy, K. R.: Observing Earth's atmosphere with radio occultation measurements using the Global Positioning System, J. Geophys. Res., 102, 23429-23465, https://doi.org/10.1029/97JD01569, 1997.

Lejenäs, H.: Characteristics of southern hemisphere blocking as determined from a time series of observational data, Q. J. Roy. Meteor. Soc., 110, 967-979, https://doi.org/10.1002/qj.49711046610, 1984.

Long, C. S., Fujiwara, M., Davis, S., Mitchell, D. M., and Wright, C. J.: Climatology and Interannual Variability of Dynamic Variables in Multiple Reanalyses Evaluated by the SPARC Reanalysis Intercomparison Project (S-RIP), Atmos. Chem. Phys. Discuss., https://doi.org/10.5194/acp-2017-289, in review, 2017.

Marques, R. d. F. C. and Rao, V. B.: A Diagnosis of a LongLasting Blocking Event over the Southeast Pacific Ocean, Mon. Weather Rev., 127, 1761-1776, https://doi.org/10.1175/15200493(1999)127<1761:ADOALL>2.0.CO;2, 1999.

Martineau, P., Chen, G., and Burrows, D. A.: Wave events: climatology, trends, and relationship to Northern Hemisphere winter blocking and weather extremes, J. Climate, 30, 5675-5697, https://doi.org/10.1175/JCLI-D-16-0692.1, 2017.

Masato, G., Hoskins, B. J., and Woollings, T.: Winter and Summer Northern Hemisphere Blocking in CMIP5 Models, J. Climate, 26, 7044-7059, https://doi.org/10.1175/JCLI-D-1200466.1, 2013

McCarty, W., Coy, L., Gelaro, R., Huang, A., Merkova, D., Smith, E. B., Sienkiewicz, M., and Wargan, K.: MERRA-2 Input Observations: Summary and Assessment, available at: https://gmao. gsfc.nasa.gov/pubs/docs/McCarty885.pdf (last access: 6 March 2017), 2016.

Melbourne, W. G., Davis, E. S., Duncan, C. B., Hajj, G. A., Hardy, K. R., Kursinski, E. R., Meehan, T. K., Young, L. E., and Yunck, T. P.: The application of spaceborne GPS to atmospheric limb sounding and global change monitoring, JPL Publication, 94-18, 147, 1994.

Oliveira, F. N. M., Carvalho, L. M. V., and Ambrizzi, T.: A new climatology for Southern Hemisphere blockings in the winter and the combined effect of ENSO and SAM phases, Int. J. Climatol., 34, 1676-1692, https://doi.org/10.1002/joc.3795, 2014.

Parker, T. J., Berry, G. J., and Reeder, M. J.: The Structure and Evolution of Heat Waves in Southeastern Australia, J. Climate, 27, 5768-5785, https://doi.org/10.1175/JCLI-D-13-00740.1, 2014.

Parker, W. S.: Reanalyses and Observations: What's the Difference?, B. Am. Meteorol. Soc., 97, 1565-1572, https://doi.org/10.1175/BAMS-D-14-00226.1, 2016.

Parsons, S., Renwick, J. A., and McDonald, A. J.: An Assessment of Future Southern Hemisphere Blocking Using CMIP5 
Projections from Four GCMs, J. Climate, 29, 7599-7611, https://doi.org/10.1175/JCLI-D-15-0754.1, 2016.

Peevey, T. R., Gille, J. C., Homeyer, C. R., and Manney, G. L.: The double tropopause and its dynamical relationship to the tropopause inversion layer in storm track regions, J. Geophys. Res., 119, 10194-10212, https://doi.org/10.1002/2014JD021808, 2014.

Pelly, J. L. and Hoskins, B. J.: A new perspective on blocking, J. Atmos. Sci., 60, 743-755, https://doi.org/10.1175/15200469(2003)060<0743:ANPOB>2.0.CO;2, 2003.

Pfahl, S. and Wernli, H.: Quantifying the relevance of atmospheric blocking for co-located temperature extremes in the Northern Hemisphere on (sub-)daily time scales, Geophys. Res. Lett., 39, L12807, https://doi.org/10.1029/2012GL052261, 2012.

Pfahl, S., Schwierz, C., Croci-Maspoli, M., Grams, C. M., and Wernli, H.: Importance of latent heat release in ascending air streams for atmospheric blocking, Nat. Geosci., 8, 610-614, https://doi.org/10.1038/ngeo2487, 2015.

Poli, P., Healy, S. B., and Dee, D. P.: Assimilation of Global Positioning System radio occultation data in the ECMWF ERAInterim reanalysis, Q. J. Roy. Meteor. Soc., 136, 1972-1990, https://doi.org/10.1002/qj.722, 2010.

Pook, M. J., Risbey, J. S., McIntosh, P. C., Ummenhofer, C. C., Marshall, A. G., and Meyers, G. A.: The Seasonal Cycle of Blocking and Associated Physical Mechanisms in the Australian Region and Relationship with Rainfall, Mon. Weather Rev., 141, 45344553, https://doi.org/10.1175/MWR-D-13-00040.1, 2013.

Randel, W. J. and Wu, F.: Kelvin wave variability near the equatorial tropopause observed in GPS radio occultation measurements, J. Geophys. Res., 110, D03102, https://doi.org/10.1029/2004JD005006, 2005.

Randel, W. J. and Wu, F.: Variability of Zonal Mean Tropical Temperatures Derived from a Decade of GPS Radio Occultation Data, J. Atmos. Sci., 72, 1261-1275, https://doi.org/10.1175/JAS-D-14-0216.1, 2015.

Randel, W. J., Wu, F., and Ríos, W. R.: Thermal variability of the tropical tropopause region derived from GPS/MET observations, J. Geophys. Res., 108, 4024, https://doi.org/10.1029/2002JD002595, 2003.

Rex, D. F.: Blocking Action in the Middle Troposphere and its Effect upon Regional Climate I: An aerological study of blocking action, Tellus, 2, 196-211, https://doi.org/10.1111/j.21533490.1950.tb00331.x, 1950.

Rieckh, T., Scherllin-Pirscher, B., Ladstädter, F., and Foelsche, U.: Characteristics of tropopause parameters as observed with GPS radio occultation, Atmos. Meas. Tech., 7, 3947-3958, https://doi.org/10.5194/amt-7-3947-2014, 2014.

Rodrigues, R. R. and Woollings, T.: Impact of Atmospheric Blocking on South America in Austral Summer, J. Climate, 30, 18211837, https://doi.org/10.1175/JCLI-D-16-0493.1, 2017.

Scherllin-Pirscher, B., Kirchengast, G., Steiner, A. K., Kuo, Y.-H., and Foelsche, U.: Quantifying uncertainty in climatological fields from GPS radio occultation: an empiricalanalytical error model, Atmos. Meas. Tech., 4, 2019-2034, https://doi.org/10.5194/amt-4-2019-2011, 2011a.

Scherllin-Pirscher, B., Steiner, A. K., Kirchengast, G., Kuo, Y.-H., and Foelsche, U.: Empirical analysis and modeling of errors of atmospheric profiles from GPS radio occultation, Atmos. Meas.
Tech., 4, 1875-1890, https://doi.org/10.5194/amt-4-1875-2011, $2011 b$.

Scherllin-Pirscher, B., Deser, C., Ho, S.-P., Chou, C., Randel, W., and Kuo, Y.-H.: The vertical and spatial structure of ENSO in the upper troposphere and lower stratosphere from GPS radio occultation measurements, Geophys. Res. Lett., 39, L20801, https://doi.org/10.1029/2012GL053071, 2012.

Scherllin-Pirscher, B., Steiner, A. K., Kirchengast, G., Schwaerz, M., and Leroy, S. S.: The power of vertical geolocation of atmospheric profiles from GNSS radio occultation, J. Geophys. Res.-Atmos., 122, 1595-1616, https://doi.org/10.1002/2016JD025902, 2017.

Scherrer, S. C., Croci-Maspoli, M., Schwierz, C., and Appenzeller, C.: Two-dimensional indices of atmospheric blocking and their statistical relationship with winter climate patterns in the Euro-Atlantic region, Int. J. Climatol., 26, 233-249, https://doi.org/10.1002/joc.1250, 2006.

Schiemann, R., Demory, M.-E., Shaffrey, L. C., Jane, S., Vidale, P. L., Mizielinski, M. S., Roberts, M. J., Matsueda, M., Wehner, M. F., and Thomas, J.: The Resolution Sensitivity of Northern Hemisphere Blocking in Four 25-km Atmospheric Global Circulation Models, J. Climate, 30, 337-358, https://doi.org/10.1175/JCLI-D-16-0100.1, 2017.

Schmidt, T., Heise, S., Wickert, J., Beyerle, G., and Reigber, C.: GPS radio occultation with CHAMP and SAC-C: global monitoring of thermal tropopause parameters, Atmos. Chem. Phys., 5, 1473-1488, https://doi.org/10.5194/acp-5-1473-2005, 2005.

Schmidt, T., Wickert, J., Beyerle, G., and Heise, S.: Global tropopause height trends estimated from GPS radio occultation data, Geophys. Res. Lett., 35, L11806, https://doi.org/10.1029/2008GL034012, 2008.

Schwärz, M., Kirchengast, G., Scherllin-Pirscher, B., Schwarz, J., Ladstädter, F., and Angerer, B.: Multi-Mission Validation by Satellite Radio Occultation - Extension Project, Final report for ESA/ESRIN No. 01/2016, WEGC, University of Graz, Graz, Austria, 2016.

Sillmann, J., Croci-Maspoli, M., Kallache, M., and Katz, R. W.: Extreme Cold Winter Temperatures in Europe under the Influence of North Atlantic Atmospheric Blocking, J. Climate, 24, 58995913, https://doi.org/10.1175/2011JCLI4075.1, 2011.

Simmons, A. J., Poli, P., Dee, D. P., Berrisford, P., Hersbach, H., Kobayashi, S., and Peubey, C.: Estimating lowfrequency variability and trends in atmospheric temperature using ERA-Interim, Q. J. Roy. Meteor. Soc., 140, 329-353, https://doi.org/10.1002/qj.2317, 2014.

Sinclair, M. R.: A Climatology of Anticyclones and Blocking for the Southern Hemisphere, Mon. Weather Rev., 124, 245-264, https://doi.org/10.1175/15200493(1996)124<0245:ACOAAB>2.0.CO;2, 1996.

Sitnov, S., Mokhov, I., and Lupo, A.: Ozone, water vapor, and temperature anomalies associated with atmospheric blocking events over Eastern Europe in spring-summer 2010, Atmos. Environ., 164, 180-194, https://doi.org/10.1016/j.atmosenv.2017.06.004, 2017.

Sousa, P. M., Trigo, R. M., Barriopedro, D., Soares, P. M. M., Ramos, A. M., and Liberato, M. L. R.: Responses of European precipitation distributions and regimes to different blocking locations, Clim. Dynam., 48, 1141-1160, https://doi.org/10.1007/s00382-016-3132-5, 2017. 
Steiner, A. K., Lackner, B. C., Ladstädter, F., Scherllin-Pirscher, B., Foelsche, U., and Kirchengast, G.: GPS radio occultation for climate monitoring and change detection, Radio Sci., 46, RS0D24, https://doi.org/10.1029/2010RS004614, 2011.

Steiner, A. K., Hunt, D., Ho, S.-P., Kirchengast, G., Mannucci, A. J., Scherllin-Pirscher, B., Gleisner, H., von Engeln, A., Schmidt, T., Ao, C., Leroy, S. S., Kursinski, E. R., Foelsche, U., Gorbunov, M., Heise, S., Kuo, Y.-H., Lauritsen, K. B., Marquardt, C., Rocken, C., Schreiner, W., Sokolovskiy, S., Syndergaard, S., and Wickert, J.: Quantification of structural uncertainty in climate data records from GPS radio occultation, Atmos. Chem. Phys., 13, 1469-1484, https://doi.org/10.5194/acp13-1469-2013, 2013.

Sun, D.-Z., Zhang, T., Sun, Y., and Yu, Y.: Rectification of El NiñoSouthern Oscillation into Climate Anomalies of Decadal and Longer Time Scales: Results from Forced Ocean GCM Experiments, J. Climate, 27, 2545-2561, https://doi.org/10.1175/JCLID-13-00390.1, 2014.

Tibaldi, S. and Molteni, F.: On the operational predictability of blocking, Tellus A, 42, 343-365, https://doi.org/10.1034/j.16000870.1990.t01-2-00003.x, 1990.

Trenberth, K. F. and Mo, K. C.: Blocking in the Southern Hemisphere, Mon. Weather Rev., 113, 3-21, https://doi.org/10.1175/15200493(1985)113<0003:BITSH>2.0.CO;2, 1985.

Trigo, R. M., Trigo, I. F., DaCamara, C. C., and Osborn, T. J.: Climate impact of the European winter blocking episodes from the NCEP/NCAR Reanalyses, Clim. Dynam., 23, 17-28, https://doi.org/10.1007/s00382-004-0410-4, 2004.
Tsuda, T.: Characteristics of atmospheric gravity waves observed using the MU (Middle and Upper atmosphere) radar and GPS (Global Positioning System) radio occultation, Proc. Jpn. Acad. Ser. B, 90, 12-27, 2014.

Vial, J. and Osborn, T. J.: Assessment of atmosphere-ocean general circulation model simulations of winter northern hemisphere atmospheric blocking, Clim. Dynam., 39, 95-112, https://doi.org/10.1007/s00382-011-1177-z, 2012.

Whan, K., Zwiers, F., and Sillmann, J.: The Influence of Atmospheric Blocking on Extreme Winter Minimum Temperatures in North America., J. Climate, 29, 4361-4381, https://doi.org/10.1175/JCLI-D-15-0493.1, 2016.

Wise, E. K.: Five centuries of U.S. West Coast drought: Occurrence, spatial distribution, and associated atmospheric circulation patterns, Geophys. Res. Lett., 43, 4539-4546, https://doi.org/10.1002/2016GL068487, 2016.

Woollings, T.: Dynamical influences on European climate: an uncertain future, Philos. T. Roy. Soc. A, 368, 3733-3756, https://doi.org/10.1098/rsta.2010.0040, 2010.

Yue, X., Schreiner, W. S., Pedatella, N., Anthes, R. A., Mannucci, A. J., Straus, P. R., and Liu, J.-Y.: Space Weather Observations by GNSS Radio Occultation: From FORMOSAT3/COSMIC to FORMOSAT-7/COSMIC-2, Space Weather, 12, 616-621, https://doi.org/10.1002/2014SW001133, 2014. 